\title{
Hydrogen Peroxide Gates a Voltage-Dependent Cation Current in Aplysia Neuroendocrine Cells
}

\author{
Alamjeet K. Chauhan and Neil S. Magoski \\ Department of Biomedical and Molecular Sciences, Experimental Medicine Graduate Program and Centre for Neuroscience Studies, Queen's University, \\ Kingston, Ontario K7L 3N6, Canada
}

\begin{abstract}
Nonselective cation channels promote persistent spiking in many neurons from a diversity of animals. In the hermaphroditic marinesnail, Aplysia californica, synaptic input to the neuroendocrine bag cell neurons triggers various cation channels, causing an $\sim 30$ min afterdischarge of action potentials and the secretion of egg-laying hormone. During the afterdischarge, protein kinase $\mathrm{C}$ is also activated, which in turn elevates hydrogen peroxide $\left(\mathrm{H}_{2} \mathrm{O}_{2}\right)$, likely by stimulating nicotinamide adenine dinucleotide phosphate oxidase. The present study investigated whether $\mathrm{H}_{2} \mathrm{O}_{2}$ regulates cation channels to drive the afterdischarge. In single, cultured bag cell neurons, $\mathrm{H}_{2} \mathrm{O}_{2}$ elicited a prolonged, concentration- and voltage-dependent inward current, associated with an increase in membrane conductance and a reversal potential of $\sim+30 \mathrm{mV}$. Compared with normal saline, the presence of $\mathrm{Ca}^{2+}$-free, $\mathrm{Na}^{+}$-free, or $\mathrm{Na}^{+} / \mathrm{Ca}^{2+}$-free extracellular saline, lowered the current amplitude and left-shifted the reversal potential, consistent with a nonselective cationic conductance. Preventing $\mathrm{H}_{2} \mathrm{O}_{2}$ reduction with the glutathione peroxidase inhibitor, mercaptosuccinate, enhanced the $\mathrm{H}_{2} \mathrm{O}_{2}$-induced current, while boosting glutathione production with its precursor, $\mathrm{N}$-acetylcysteine, or adding the reducing agent, dithiothreitol, lessened the response. Moreover, the current generated by the alkylating agent, $\mathrm{N}$-ethylmaleimide, occluded the effect of $\mathrm{H}_{2} \mathrm{O}_{2}$. The $\mathrm{H}_{2} \mathrm{O}_{2}$-induced current was inhibited by tetrodotoxin as well as the cation channel blockers, 9-phenanthrol and clotrimazole. In current-clamp, $\mathrm{H}_{2} \mathrm{O}_{2}$ stimulated burst firing, but this was attenuated or prevented altogether by the channel blockers. Finally, $\mathrm{H}_{2} \mathrm{O}_{2}$ evoked an afterdischarge from whole bag cell neuron clusters recorded ex vivo by sharp-electrode. $\mathrm{H}_{2} \mathrm{O}_{2}$ may regulate a cation channel to influence long-term changes in activity and ultimately reproduction.
\end{abstract}

Key words: bursting; $\mathrm{H}_{2} \mathrm{O}_{2}$; mollusk; peptidergic neuron; redox; reproduction

\section{Significance Statement}

Hydrogen peroxide $\left(\mathrm{H}_{2} \mathrm{O}_{2}\right)$ is often studied in a pathological context, such as ischemia or inflammation. However, $\mathrm{H}_{2} \mathrm{O}_{2}$ also physiologically modulates synaptic transmission and gates certain transient receptor potential channels. That stated, the effect of $\mathrm{H}_{2} \mathrm{O}_{2}$ on neuronal excitability remains less well defined. Here, we examine how $\mathrm{H}_{2} \mathrm{O}_{2}$ influences Aplysia bag cell neurons, which elicit ovulation by releasing hormones during an afterdischarge. These neuroendocrine cells are uniquely identifiable and amenable to recording as individual cultured neurons or a cluster from the nervous system. In both culture and the cluster, $\mathrm{H}_{2} \mathrm{O}_{2}$ evokes prolonged, afterdischarge-like bursting by gating a nonselective voltage-dependent cationic current. Thus, $\mathrm{H}_{2} \mathrm{O}_{2}$, which is generated in response to afterdischarge-associated second messengers, may prompt the firing necessary for hormone secretion and procreation.

\section{Introduction}

Reactive oxygen species are generated either as a byproduct of oxidative metabolism (Babior et al., 1973; Kourie, 1998) or via

\footnotetext{
Received March 28, 2019; revised 0ct. 7, 2019; accepted 0ct. 27, 2019.

Author contributions: A.K.C. and N.S.M. designed research; A.K.C. performed research; A.K.C. and N.S.M. analyzed data; A.K.C. and N.S.M. wrote the paper.

This work was supported by a Canadian Institutes of Health Research operating Grant (MOP111211) and project Grant (PJT-159794) to N.S.M. We thank C. A. London for technical support, and C. B. Beekharry and C. J. Groten for preliminary assistance with the $\mathrm{H}_{2} \mathrm{O}_{2}$-induced response.

The authors declare no competing financial interests.

Correspondence should be addressed to Neil S. Magoski at magoski@queensu.ca.
}

NADPH oxidase (Bedard and Krause, 2007). $\mathrm{O}_{2}$ is reduced to the superoxide anion radical, $\mathrm{O}_{2} \cdot-$, which is in turn dismutated to the more stable and freely diffusible hydrogen peroxide $\left(\mathrm{H}_{2} \mathrm{O}_{2}\right.$; Brookes et al., 2004; Bedard and Krause, 2007; Lee et al., 2015a). Elevated reactive oxygen species can lead to stress and cell death, potentially contributing to aging (Sohal and Orr, 2012) or Alzheimer's and Parkinson's diseases (Hernandes and Britto, 2012). However, growing evidence shows that $\mathrm{H}_{2} \mathrm{O}_{2}$ may regulate ion

https://doi.org/10.1523/JNEUROSCI.1460-19.2019

Copyright $\odot 2019$ the authors 
channels physiologically; for example, in the substantia nigra, $\mathrm{H}_{2} \mathrm{O}_{2}$ hyperpolarizes dopaminergic neurons by gating an ATPsensitive $\mathrm{K}^{+}$channel, and depolarizes GABAergic neurons by gating a nonselective cation channel (Avshalumov et al., 2005; Lee et al., 2011).

Cation channels underlie bursting and persistent firing in many neurons (Partridge et al., 1994; Major and Tank, 2004). This includes cation channel-dependent protracted spiking in the snails, Aplysia (Kramer and Zucker, 1985; Matsumoto et al., 1988), Archidoris (Partridge et al., 1979), and Helix (Swandulla and Lux, 1985; Partridge and Swandulla, 1987). For rodents, cation channels mediate long-lasting activity in lumbosacral spinal cord (Derjean et al., 2005), dorsal horn (Morisset and Nagy, 2000), olfactory bulb (Shpak et al., 2012), substantia nigra (Mrejeru et al., 2011), and rostral ambiguus (Rekling and Feldman, 1997), as well as hippocampal (Knauer et al., 2013), anterior cingulate (Ratté et al., 2018), entorhinal (Tahvildari et al., 2008), and prefrontal cortex (Yan et al., 2009; Baker et al., 2018). Functionally, cation channels impact memory (Egorov et al., 2002; Sidiropoulou et al., 2009), sensory coding (Dong et al., 2009), motor pattern generation (Di Prisco et al., 1997), and neuroendocrine control (Chakfe and Bourque, 2000).

The bag cell neurons are neuroendocrine cells that initiate reproduction in Aplysia (Conn and Kaczmarek, 1989; Zhang and Kaczmarek, 2008; Sturgeon et al., 2018). In response to cholinergic input, these neurons depolarize and undergo a lengthy afterdischarge, with both a fast-phase $(\sim 5 \mathrm{~Hz}, \sim 1 \mathrm{~min})$ and slow-phase $(1 \mathrm{~Hz}, \sim 30 \mathrm{~min})$ of action potential firing that results in the neurohemal secretion of egg-laying hormone (Kupfermann and Kandel, 1970; Arch, 1972; Pinsker and Dudek, 1977; Loechner et al., 1990; Roubos et al., 1990; Michel and Wayne, 2002; Hatcher and Sweedler, 2008; White and Magoski, 2012). The hormone engages both central neurons and peripheral organs to induce behaviors that culminate in the deposition of fertilized eggs (Arch and Smock, 1977; Stuart and Strumwasser, 1980; Rothman et al., 1983). The afterdischarge is maintained by opening of three, distinct cation channels: a voltage-independent channel gated by calmodulin-kinase (Hung and Magoski, 2007; Hickey et al., 2010), a separate voltage-independent channel triggered by diacylglycerol (DAG; Sturgeon and Magoski, 2016), and $\mathrm{a} \mathrm{Ca}^{2+}$-permeable, $\mathrm{Ca}^{2+}$-activated, voltage-dependent channel (Wilson et al., 1996; Lupinsky and Magoski, 2006; Geiger et al., 2009). Munnamalai et al. (2014) showed that NADPH oxidase is present in bag cell neurons, and protein kinase $\mathrm{C}$ (PKC), which is activated early in the slow-phase of the afterdischarge (Wayne et al., 1999), stimulates $\mathrm{H}_{2} \mathrm{O}_{2}$ production. This likely occurs through PKC-mediated phosphorylation of the NADPH oxidase cytosolic regulatory subunit, $\mathrm{p} 7^{\text {phox }}$ (Fontayne et al., 2002). Thus, we sought to test whether $\mathrm{H}_{2} \mathrm{O}_{2}$ can affect bag cell neuron function in a manner concordant with afterdischarge generation. The present study shows that exogenous $\mathrm{H}_{2} \mathrm{O}_{2}$ triggers a conductance similar to the voltage-dependent cation channel previously characterized in bag cell neurons. This $\mathrm{H}_{2} \mathrm{O}_{2}$-induced current is sensitive to both changes in redox and cation channel blockers; moreover, it produces prolonged depolarization and firing. Historically, excessive $\mathrm{H}_{2} \mathrm{O}_{2}$ has been implicated in neuronal cell death (Herson and Ashford, 1997; Herson et al., 1999; Smith et al., 2003); however, along with work on substantia nigra (Lee et al., 2011, 2013) and hippocampal (Olah et al., 2009) neurons, our results suggest a role for $\mathrm{H}_{2} \mathrm{O}_{2}$ in regulating persistent firing. In Aplysia, such regulation may have consequences for procreation.

\section{Materials and Methods}

Animals and cell culture. Adult Aplysia californica (a hermaphrodite) weighing 200-650 g were obtained from Marinus and housed in an $\sim 300 \mathrm{~L}$ aquarium containing continuously circulating, aerated sea water (Instant Ocean, Aquarium Systems) at $16-18^{\circ} \mathrm{C}$ on a $12: 12 \mathrm{~h}$ light/dark cycle and fed romaine lettuce five times/week. All experiments were approved by the Queen's University Animal Care Committee (protocols 2013-041 and 2017-1745).

For primary cultures of isolated bag cell neurons, animals were anesthetized by an injection of isotonic $\mathrm{MgCl}_{2}(0.39 \mathrm{M}$; volume $\sim 50 \%$ of body weight), and the abdominal ganglion was removed and treated with dispase II (13.3 mg/ml; 04942078601, Roche Diagnostics/Sigma-Aldrich) dissolved in tissue culture artificial sea water (tcASW; composition in mм: $460 \mathrm{NaCl}, 10.4 \mathrm{KCl}, 11 \mathrm{CaCl}_{2}, 55 \mathrm{MgCl}_{2}, 15 \mathrm{HEPES}, 1 \mathrm{mg} / \mathrm{ml}$ glucose, $100 \mathrm{U} / \mathrm{ml}$ penicillin plus $0.1 \mathrm{mg} / \mathrm{ml}$ streptomycin (P4333, SigmaAldrich), pH 7.8 with $\mathrm{NaOH}$, for $18 \mathrm{~h}$ at $22^{\circ} \mathrm{C}$. The ganglion was then rinsed in tcASW for $1 \mathrm{~h}$, and the two bag cell neuron clusters were dissected from their surrounding connective tissue. Using a fire-polished glass Pasteur pipette and gentle trituration, neurons were dissociated and dispersed in tcASW onto $35 \times 10 \mathrm{~mm}$ polystyrene tissue culture dishes (353001, Falcon-Corning/ThermoFisher Scientific). Cultures were maintained in a $14^{\circ} \mathrm{C}$ incubator and used for experimentation within 1-3 d. Salts were obtained from ThermoFisher Scientific, MP Biomedicals, Acros Organics, or Sigma-Aldrich.

Whole-cell voltage-clamp and current-clamp recording from cultured bag cell neurons. Tight-seal, whole-cell recordings of membrane current or voltage from cultured bag cell neurons were performed at room temperature $\left(20-22^{\circ} \mathrm{C}\right)$ using an EPC-8 amplifier (HEKA Electronik/Harvard Apparatus). Borosilicate-glass microelectrodes had a resistance of 1-2 $\mathrm{M} \Omega$ when filled with various intracellular saline (see following paragraph). Pipette and membrane capacitive currents were cancelled and the series resistance (3-5 M $\Omega$ ) compensated to $70-80 \%$. Current was lowpass filtered at $1 \mathrm{kHz}$ and sampled at $2 \mathrm{kHz}$ using a Digidata $1322 \mathrm{~A}$ analog-to-digital converter (Molecular Devices) and the Clampex acquisition program of pCLAMP v8.1 (Molecular Devices). Holding and test potentials (see Results) were delivered using pCLAMP. Voltage was lowpass filtered at $5 \mathrm{kHz}$ and sampled as per current; in addition, membrane potential was initially set to -60 or $-40 \mathrm{mV}$ with constant bias current from the EPC-8.

Unless otherwise noted, most recordings were made in normal artificial sea water (nASW; composition as per tcASW but lacking glucose and antibiotics) with a $\mathrm{Cs}^{+}$-based intracellular saline (composition in $\mathrm{mm:}$ $500 \mathrm{Cs}^{+}$-Asp, $70 \mathrm{KCl}, 1.25 \mathrm{MgCl}_{2}, 10$ HEPES, 11 glucose, 10 glutathione, 5 EGTA, 5 adenosine $5^{\prime}$-triphosphate $2 \mathrm{Na}^{\circ} \mathrm{H}_{2} \mathrm{O}$ (A3377, Sigma-Aldrich), and 0.1 guanosine $5^{\prime}$-triphosphate $\mathrm{Na} \cdot \mathrm{H}_{2} \mathrm{O}$ (G8877, Sigma-Aldrich), $\mathrm{pH}$ 7.3 with $\mathrm{KOH}$. Some experiments used $\mathrm{a} \mathrm{K}^{+}$-based intracellular saline as per the $\mathrm{Cs}^{+}$-based saline, but with $\mathrm{K}^{+}$replacing $\mathrm{Cs}^{+}$. For both intracellular salines, as calculated using WebMaxC (https://somapp.ucdmc. ucdavis.edu/pharmacology/bers/maxchelator/webmaxc/webmaxcS. htm), $3.75 \mathrm{mM} \mathrm{CaCl}_{2}$ was added to set the free $\mathrm{Ca}^{2+}$ concentration at 300 $\mathrm{nM}$, which corresponds to the approximate resting intracellular $\mathrm{Ca}^{2+}$ concentration of bag cell neurons as determined using either $\mathrm{Ca}^{2+}$ sensitive electrodes (Fisher et al., 1994) or imaging of $\mathrm{Ca}^{2+}$-sensitive dyes (Fink et al., 1988; Loechner et al., 1992; Knox et al., 1996; Magoski et al., 2000). Junction potentials of 17 and $15 \mathrm{mV}$ were calculated for the $\mathrm{Cs}^{+}$-based and $\mathrm{K}^{+}$-based intracellular salines, respectively, versus nASW and compensated for by subtraction off-line. In a small number of experiments, voltage-gated $\mathrm{Ca}^{2+}$ current was recorded by using the $\mathrm{Cs}^{+}$-based intracellular saline and an ASW where all of the $\mathrm{Na}^{+}$and $\mathrm{K}^{+}$ were replaced with tetraethylammonium and $\mathrm{Cs}^{+}$, respectively. The 20 $\mathrm{mV}$ junction potential for this saline combination was compensated for by subtraction off-line.

Experiments designed to examine the reversal potentials of the $\mathrm{H}_{2} \mathrm{O}_{2}$ induced current involved external $\mathrm{Na}^{+}$and $\mathrm{Ca}^{2+}$ substitutions to make $\mathrm{Na}^{+}$-free [composition as per nASW but with the $\mathrm{Na}^{+}$replaced by $\mathrm{N}$-methyl-D-glucamine (NMDG)], $\mathrm{Ca}^{2+}$-free $\left(\mathrm{Ca}^{2+}\right.$ replaced by $\left.\mathrm{Mg}^{2+}\right)$, and $\mathrm{Na}^{+} / \mathrm{Ca}^{2+}$-free $\left(\mathrm{Na}^{+}\right.$replaced by NMDG and $\mathrm{Ca}^{2+}$ replaced by $\mathrm{Mg}^{2+}$ ) salines. Junction potentials of $17 \mathrm{mV}$ for $\mathrm{Ca}^{2+}$-free 
ASW and $23 \mathrm{mV}$ for both $\mathrm{Na}^{+}$-free ASW and $\mathrm{Na}^{+} / \mathrm{Ca}^{2+}$-free ASW versus the $\mathrm{Cs}^{+}$-based intracellular saline were compensated for by subtraction off-line.

Ensemble extracellular recording from the intact bag cell neuron cluster. For extracellular recording, the abdominal ganglion, including the two bag cell neuron clusters and associated pleuroabdominal connectives, was isolated and maintained in nASW-filled dish kept at a $14^{\circ} \mathrm{C}$ by immersion in a water-cooled chamber. A wide-bore, fire-polished glass suction recording electrode (containing nASW) was placed over one of the two bag cell neuron clusters, while a similarly fashioned stimulating electrode was placed at the rostral end of the pleuroabdominal connective ipsilateral to the recorded cluster. Synaptic input was stimulated with current from a Grass SD9 stimulator (Astro-Med) while voltage was monitored with a Model 3000 AC/DC differential amplifier (A-M Systems). Voltage was high-pass filtered at $10 \mathrm{~Hz}$ and low-pass filtered at $1 \mathrm{kHz}$, and acquired at $2 \mathrm{kHz}$ using AxoScope v9.0 (Molecular Devices) as per whole-cell voltageclamp.

Sharp-electrode recording from bag cell neurons in culture and isolated clusters. Sharpelectrode recordings from bag cell neurons were performed using an AxoClamp 2B amplifier (Molecular Devices) at room temperature $\left(20-22^{\circ} \mathrm{C}\right)$. Borosilicate-glass microelectrodes had a resistance of 5-20 M $\Omega$ when filled with 2 $\mathrm{M} \mathrm{K}^{+}$-acetate plus $10 \mathrm{~mm}$ HEPES and $100 \mathrm{~mm}$ $\mathrm{KCl}, \mathrm{pH} 7.3$ with $\mathrm{KOH}$. Voltage-clamp was performed on single, cultured bag cell neurons using continuous single-electrode voltage-clamp at a holding potential of $-30 \mathrm{mV}$. Whereas current-clamp was undertaken on bag cell neurons in desheathed, isolated clusters using the bridge-balance method. A Grass S88 stimulator was used to deliver $50 \mathrm{~ms}$ hyperpolarizing current pulses to balance the bridge; in addition, bias current was injected into the neuron as necessary from the AxoClamp. Current or voltage was filtered to $3 \mathrm{kHz}$ before sampling at $2 \mathrm{kHz}$ as per whole-cell voltage-clamp with Clampex.

Drug application and reagents. Solution exchanges were initially accomplished using a calibrated transfer pipette to replace the bath (culture dish) tcASW with the desired extracellular saline before the start of a given experiment. In most cases, drugs were introduced before or during recording by initially removing a small volume $(\sim 50 \mu \mathrm{l})$ of saline from the bath, combining that with an even smaller volume $(<10 \mu \mathrm{l})$ of drug stock-solution (see following paragraph), and then reintroducing that mixture back into the bath. Care was taken to pipette near the side of the dish and as far away as possible from the neuron. For some experiments, drugs or transmitters were applied using a single-cell superfusion system consisting of a micromanipulator-controlled square-barreled glass pipette ( $\sim 500 \mu \mathrm{m}$ bore; 8250 , VitroCom) positioned $300-500 \mu \mathrm{m}$ from the soma and connected by a stopcock manifold to a series of gravity-driven reservoirs. This provided a constant flow $(\sim 0.5-1 \mathrm{ml} / \mathrm{min})$ of control extracellular saline over the neuron, which was switched to drug-containing saline by activating the appropriate stopcock. The bath volume was kept constant during superfusion with vacuum-trap suction outlet.

Water was used to dissolve the following as stocks at the indicated concentrations: $\mathrm{H}_{2} \mathrm{O}_{2} 0.2 \mathrm{M}$ (H325-500, ThermoFisher Scientific), mercaptosuccinic acid (0.3 M; M6182; Sigma-Aldrich), acetylcholine chloride (ACh; 100 mm; A6625, Sigma-Aldrich), DL-dithiothreitol (DTT; 50 mм; 646563, Sigma-Aldrich), 1-(2-(3-(4-methoxyphenyl)propoxy)4-methoxyphenylethyl)-1H-imidazole (SKF-96365; $50 \mathrm{~mm}$; S7809, Sigma-Aldrich), tetrodotoxin (TTX; $3 \mathrm{~mm}$; T-550, Alomone Labs), and $\mathrm{N}$-acetyl-L-cysteine (NAC; $150 \mathrm{~mm}$; A7250, Sigma-Aldrich). Similarly, dimethyl sulfoxide (DMSO; BP231-1, ThermoFisher Scientific) was used to dissolve the following: clotrimazole ( $25 \mathrm{~mm}$; C6019, Sigma-Aldrich), and 9-phenanthrol (9-Pt; 50 mm; 211281, Sigma-Aldrich). Last, ethanol (100\% v/v) was used to dissolve $N$-ethylmaleimide (NEM; 50 mm; E3876, SigmaAldrich). The final concentration of DMSO or ethanol in the bath was $\leq 0.2 \%(\mathrm{v} / \mathrm{v})$, which in control experiments here or in prior studies was found to have no effect on bag cell neuron holding current, membrane conductance, or membrane potential (Hickey et al., 2010, 2013; Tam et al., 2011; Sturgeon and Magoski, 2016; White et al., 2018).

Analysis. The Clampfit analysis program of pCLAMP was used to determine the amplitude of changes to membrane current or potential evoked by $\mathrm{H}_{2} \mathrm{O}_{2}$ or other reagents under voltage- or current-clamp. For peak change, two cursors were placed $30 \mathrm{~s}$ apart, $30 \mathrm{~s}$ before drug addition, the average between the cursors served as a baseline. An additional two cursors were placed $60 \mathrm{~s}$ apart on either side of the peak of the response. Clampfit then calculated the peak amplitude relative to the baseline. Percent recovery of the current following a response was determined by comparing the peak current to the steady-state current, the latter being calculated by again placing two cursors, $30 \mathrm{~s}$ apart, at the end of the trace, well after the maximal response and where the response had recovered to steady-state. For display only, some current traces were filtered off-line to between 50 and $100 \mathrm{~Hz}$ using the Clampfit Gaussian filter. Due to the overall slow nature of the responses, this second filtering brought about no change in amplitude or kinetics. Conductance was derived using Ohm's law $(G=I / V)$ and the current change during a 200 ms step from -30 to $-40 \mathrm{mV}$ before and after $\mathrm{H}_{2} \mathrm{O}_{2}$. Reversal potential involved taking a difference current, ascertained by subtracting the current elicited by a voltage ramp from -60 to $+60 \mathrm{mV}$ before $\mathrm{H}_{2} \mathrm{O}_{2}$ superfusion, from the current elicited by the same ramp at the peak of the $\mathrm{H}_{2} \mathrm{O}_{2}$-induced current. The reversal potential was then measured directly from the difference current by placing a cursor where the current crossed the $y$-axis. For some responses recorded under current-clamp that presented with robust spiking, which made it difficult to visualize the peak depolarization, Clampfit was used to generate all-point histograms for before and after $\mathrm{H}_{2} \mathrm{O}_{2}$ application. The largest peaks of the resulting histograms were fit with a Gaussian function by the least-squares method and a simplex search, and taken as the average membrane potential. The 

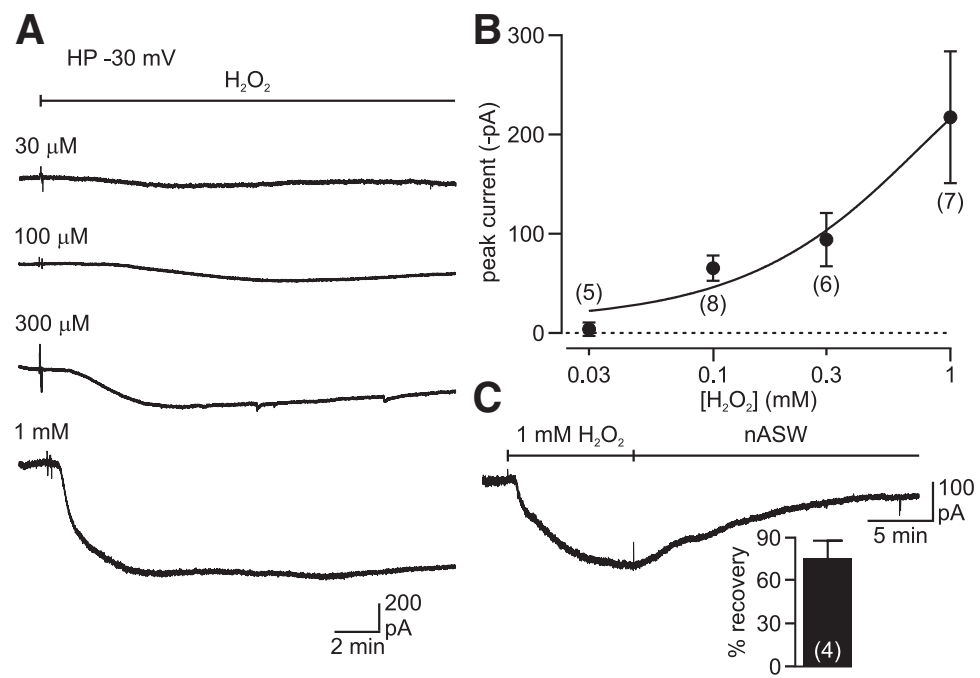

Figure 2. A concentration-dependent $\mathrm{H}_{2} \mathrm{O}_{2}$-induced inward current. $A$, Current responses to bath-applied $30 \mu \mathrm{m}, 100 \mu \mathrm{m}, 300$ $\mu \mathrm{m}$, or $1 \mathrm{~mm} \mathrm{H}_{2} \mathrm{O}_{2}$ (at bar) for different cultured bag cell neurons whole-cell voltage-clamped at $-30 \mathrm{mV}$ in nASW with Cs ${ }^{+}$-Aspbased intracellular saline. Scale bars apply to all traces. $\boldsymbol{B}$, Concentration-response curve reveals increasingly higher amounts of $\mathrm{H}_{2} \mathrm{O}_{2}$ induces progressively larger currents $(30 \mu \mathrm{M}=4.0 \pm 7.0 \mathrm{pA}, 100 \mu \mathrm{M}=66.0 \pm 13.0 \mathrm{pA}, 300 \mu \mathrm{M}=94.0 \pm 27.0 \mathrm{pA}, 1 \mathrm{~mm}$ $\mathrm{H}_{2} \mathrm{O}_{2}=218.0 \pm 66.0 \mathrm{pA}$ ). The line represents the fit of the data with a four-parameter dose-response equation, and provides an $\mathrm{EC}_{50}$ of $14.2 \mathrm{~mm}$ with a Hill slope of 0.64 . C, Upon washout of $1 \mathrm{~mm} \mathrm{H}_{2} \mathrm{O}_{2}$ with nASW, at the height of the response, the current recovered largely back to the baseline. Inset, Summary graph shows $73.0 \pm 10.6 \%$ recovery, calculated by comparing the baseline (before $\mathrm{H}_{2} \mathrm{O}_{2}$ superfusion) and the stable current at end of the trace.
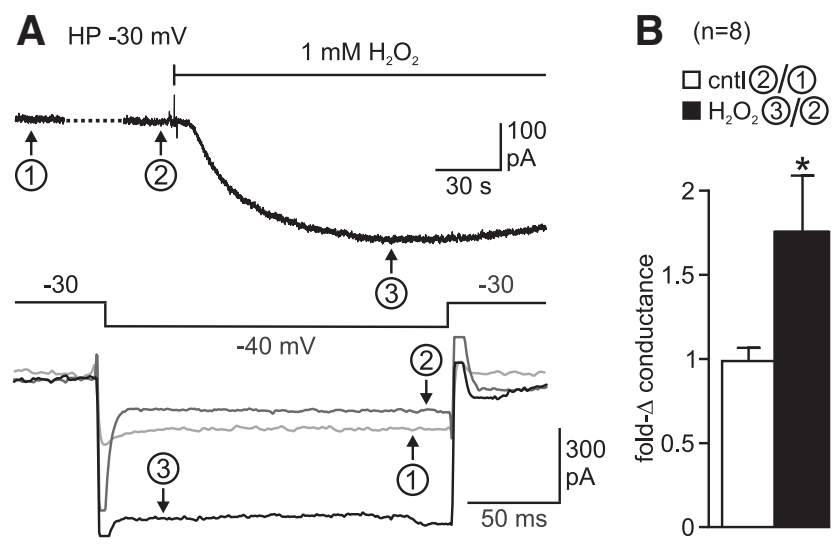

Figure 3. $\mathrm{H}_{2} \mathrm{O}_{2}$ increases membrane conductance. $A$, Top, Typical example of $1 \mathrm{~mm} \mathrm{H}_{2} \mathrm{O}_{2}$ superfusion (at bar) evoking a current in a bag cell neuron whole-cell voltage-clamped at $-30 \mathrm{mV}$ in nASW using $\mathrm{Cs}^{+}$-based intracellular saline. Middle, To determine membrane conductance, a $200 \mathrm{~ms}$ step to $-40 \mathrm{mV}$ is given $\sim 90 \mathrm{~s}$ before $\mathrm{H}_{2} \mathrm{O}_{2}$ (arrow, circled 1). A second step is taken right before $\mathrm{H}_{2} \mathrm{O}_{2}$ delivery (circled 2), whereas a third step is taken at the peak of the response (circled 3). Bottom, The current evoked by the step is markedly elevated at the peak of the $\mathrm{H}_{2} \mathrm{O}_{2}$ current (3; black trace) compared with that taken immediately ( 2 ; dark gray) or $\sim 90$ s before $\mathrm{H}_{2} \mathrm{O}_{2}$ (1; light gray). $\boldsymbol{B}$, Summary graph shows a significant increase in fold-change conductance, calculated by obtaining the ratios of the step-current taken just before $\mathrm{H}_{2} \mathrm{O}_{2}$ superfusion versus $\sim 90 \mathrm{~s}$ earlier (control $2 / 1=$ $1.0 \pm 0.079)$ and during $\mathrm{H}_{2} \mathrm{O}_{2}$ versus just before superfusion $\left(\mathrm{H}_{2} \mathrm{O}_{2} 3 / 2=1.7 \pm 0.33 ; r=0.02381\right.$; ${ }^{*} p=0.0078$, Wilcoxon matched-pairs signed ranks test).

difference between the voltage before and after $\mathrm{H}_{2} \mathrm{O}_{2}$ served as the amplitude of the depolarization. To determine the frequency of firing caused by $\mathrm{H}_{2} \mathrm{O}_{2}$, the number of spikes during the response was determined using the Clampfit threshold search function, and was divided by the total time of the burst (in seconds) to derive action potential frequency.

Experimental design and statistical analysis. Data are mean \pm SEM. Statistical analysis was performed using InStat v3.10 and Prism v8.0.0. The Kolmogorov-Smirnov method was used to test for normality. To test whether the mean differed between two groups of normally distributed data, Student's unpaired $t$ test with Welch correction as necessary was used, whereas for not normally distributed data, the Mann-Whitney $U$ test or Wilcoxon matched-pairs signed ranks test was used. For three or more means, normally distributed data were compared using an ordinary oneway ANOVA followed by the Tukey-Kramer multiple-comparisons test or Dunnett multiplecomparisons test, whereas not normally distributed data were compared using a KruskalWallis ANOVA (KW-ANOVA) followed by Dunn's multiple-comparisons test. Significance level was a two-tailed $p$ value of $<0.05$. Prism was also used to fit the $\mathrm{H}_{2} \mathrm{O}_{2}$ concentration-response relationship with a four-parameter dose-response equation to determine the half-maximal concentration $\left(\mathrm{EC}_{50}\right)$ and the Hill slope (steepness of the curve).

\section{Results}

$\mathrm{H}_{2} \mathrm{O}_{2}$ activates a prolonged, inward voltage-dependent current in cultured bag cell neurons

$\mathrm{H}_{2} \mathrm{O}_{2}$ has been shown to induce changes in the excitability of sensory neurons in Aplysia, as well as striatal, substantia nigra, spinal ventral horn, hippocampal, or cortical neurons (Chen et al., 2001; Chang et al., 2003; Olah et al., 2009; Lee et al., 2011, 2013; Ohashi et al., 2016). Given that PKC, which is upregulated 2-5 min from the onset of the afterdischarge (Wayne et al., 1999), can increase $\mathrm{H}_{2} \mathrm{O}_{2}$ production in bag cell neurons (Munnamalai et al., 2014), we examined the effects of extracellularly applied $\mathrm{H}_{2} \mathrm{O}_{2}$ on bag cell neurons in primary culture.

Initially, the efficacy of the superfusion apparatus was assessed to ascertain the exact time of $\mathrm{H}_{2} \mathrm{O}_{2}$ delivery to the neuron. This involved superfusing (see Materials and Methods, Drug application and reagents) $1 \mathrm{~mm}$ ACh over the soma of a neuron under whole-cell voltage-clamp at $-60 \mathrm{mV}$ (Fig. $1 A$, left). We previously established that ACh gates, with essentially no delay, an ionotropic receptor in bag cell neurons (White and Magoski, 2012). This ligand-gated channel opens as soon as ACh contacts the cell, and is sensitive to classic nicotinic-type agonists and antagonists (White and Magoski, 2012; White et al., 2014). Thus, the latency from when the ACh-containing reservoir was opened to when the ACh-induced current was first observed represented the lag time of our perfusion apparatus.

Neurons were bathed in $\mathrm{Na}^{+}$-containing nASW and dialyzed for 15 min with our standard $\mathrm{K}^{+}$-Asp-based intracellular saline (see Materials and Methods, Whole-cell voltage-clamp and current-clamp recording from cultured bag cell neurons). ACh induced an inward current of $\sim 3 \mathrm{nA}$ with a mean onset latency of $38 \pm 5.3 \mathrm{~s}(n=4)$ from the time superfusion began, i.e., when the stopcock on the reservoir was switched (Fig. $1 A$, middle, right). Subsequently, it was assumed that when $\mathrm{H}_{2} \mathrm{O}_{2}$ was superfused it took $38 \mathrm{~s}$ to reach the soma. Parenthetically, we performed a second calibration using block of voltage-gated $\mathrm{Ca}^{2+}$ current by $10 \mathrm{mM} \mathrm{Ni}^{2+}$, which inhibits the $\mathrm{Ca}^{2+}$ current almost instantly (Hung and Magoski, 2007). $\mathrm{Ca}^{2+}$ current was evoked at a frequency of $1 \mathrm{~Hz}$ using a $75 \mathrm{~ms}$ step from -60 to $0 \mathrm{mV}$; when the perfusion was switched from control saline to $\mathrm{Ni}^{2+}$-containing saline, it required $40 \pm 3.5 \mathrm{~s}$ for $\mathrm{Ni}^{2+}$ to initiate block $(n=10)$. This lag time was not significantly different from that observed 
A
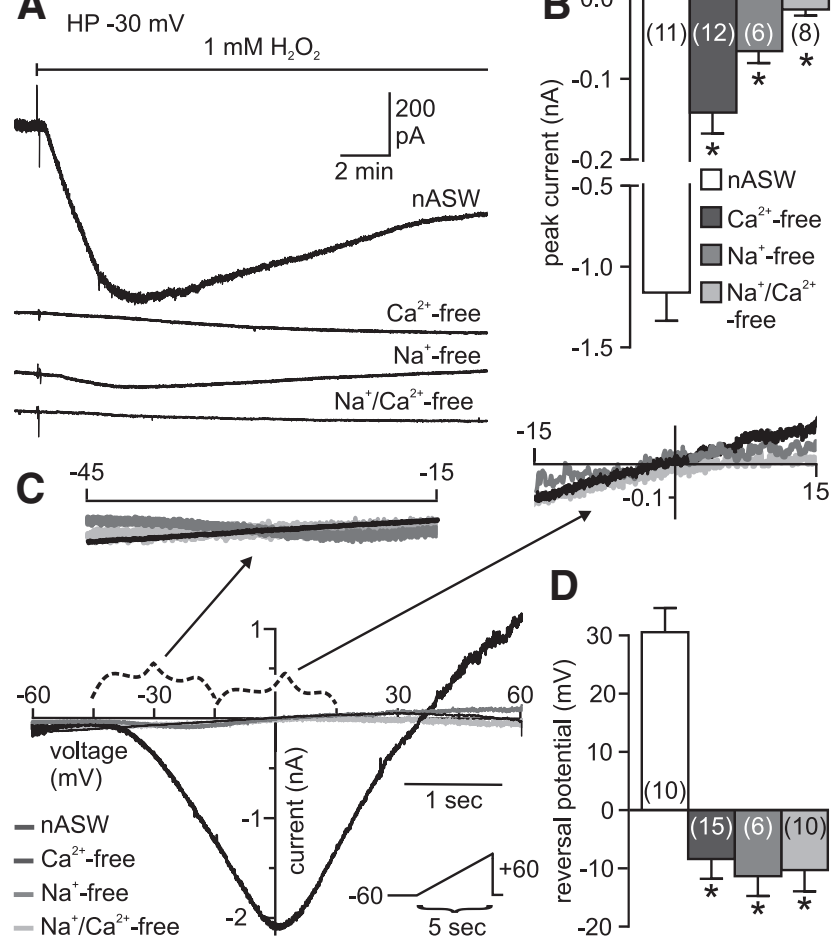

Figure 4. The $\mathrm{H}_{2} \mathrm{O}_{2}$-induced current is sensitive to change in extracellular cations. $A$, Different individual cultured bag cell neurons under whole-cell voltage-clamp at $-30 \mathrm{mV}$ using $\mathrm{Cs}^{+}$-based intracellular saline. Compared with the current elicited by $1 \mathrm{~mm} \mathrm{H}_{2} \mathrm{O}_{2}$ (at bar) in $\mathrm{Na}^{+}$-containing $\mathrm{nASW}$, the response is smaller in $\mathrm{Ca}^{2+}$-free or $\mathrm{Na}^{+}$-free saline, and mostly eliminated in $\mathrm{Na}^{+} / \mathrm{Ca}^{2+}$-free saline. Scale bars apply to all traces. $B$, Group data show that, in contrast to nASW $(1.2 \pm 0.2 \mathrm{nA}), \mathrm{Ca}^{2+}$-free $(151.6 \pm 26.4 \mathrm{pA}), \mathrm{Na}^{+}$-free $(65.3 \pm 15.3 \mathrm{pA})$, or $\mathrm{Na}^{+} / \mathrm{Ca}^{2+}$-free saline $(14.1 \pm 7.6 \mathrm{pA})$ all significantly reduce the current $(H=29.991$; $\mathrm{df}=2 ; p<0.0001, \mathrm{KW}-$ ANOVA $^{*} p<0.05 \mathrm{nASW} \mathrm{vs} \mathrm{Ca}^{+}{ }^{-}$free; ${ }^{*} p<0.01 \mathrm{nASW}$ vs Na ${ }^{+}$-free; ${ }^{*} p<0.001, n A S W$ vs Na ${ }^{+} / \mathrm{Ca}^{2+}$-free, Dunn's multiple-comparisons test). C, Difference currents obtained by subtracting the response to a $5 \mathrm{~s},-60$ to $+60 \mathrm{mV}$ voltage ramp (bottom inset), taken immediately before $1 \mathrm{~mm} \mathrm{H}_{2} \mathrm{O}_{2}$ application, from that taken at the peak of the response. For nASW (black trace), the current is voltage-dependent and reverses between +30 and $+40 \mathrm{mV}$. Upper insets show magnified $\mathrm{Ca}^{2+}$-free (dark gray), $\mathrm{Na}^{+}$-free (medium gray), and $\mathrm{Na}^{+} / \mathrm{Ca}^{2+}$-free (light gray) difference currents from -45 to $-15 \mathrm{mV}$ (left) and -15 to $+15 \mathrm{mV}$ (right). $\boldsymbol{D}$, Average data illustrates a significant left-shift in reversal potential from $\mathrm{nASW}(30.6 \pm 4.1 \mathrm{mV})$ with $\mathrm{Ca}^{2+}$-free $(-8.4 \pm 3.4 \mathrm{mV}), \mathrm{Na}^{+}$-free $(-11.3 \pm 3.4 \mathrm{mV})$, or $\mathrm{Na}^{+} / \mathrm{Ca}^{2+}$-free $(-10.3 \pm 3.7 \mathrm{mV})$ saline $\left(F_{(3,37)}=27.329 ; p<0.0001\right.$, ordinary ANOVA; ${ }^{*} p<0.01, \mathrm{nASW}$ vs $\mathrm{Ca}^{2+}$-free, nASW vs Na ${ }^{+}$-free, and nASW vs $\mathrm{Na}^{+} / \mathrm{Ca}^{2+}$-free saline, Dunnett multiple-comparisons test). Bars as per panel $\boldsymbol{B}$.

for response onset of the ACh-induced current $\left(t_{(12)}=0.3097\right.$; $p=0.7621$, unpaired Student's $t$ test).

Superfusion of $1 \mathrm{mM} \mathrm{H}_{2} \mathrm{O}_{2}$ dissolved in nASW while holding the membrane potential at $-60,-40,-30,-20$, or $0 \mathrm{mV}$ elicited a voltage-dependent inward current (Fig. 1B). There was minimal current $(<100 \mathrm{pA})$ at $-60 \mathrm{mV}(n=6)$ or $-40 \mathrm{mV}(n=4)$, whereas more moderate currents $(200-300 \mathrm{pA})$ were evoked at $-30(n=4)$ or $-20 \mathrm{mV}(n=6)$, with the maximal current $(\sim 800 \mathrm{pA})$ at $0 \mathrm{mV}(n=5 ;$ Fig. $1 C)$. At $-30 \mathrm{mV}$, the latency from when $\mathrm{H}_{2} \mathrm{O}_{2}$ arrived at the cell to when the current began was $\sim 60$ s $(n=4$; Fig. $1 D)$.

\section{A concentration-dependent $\mathrm{H}_{2} \mathrm{O}_{2}$-induced inward current}

To assess the sensitivity of bag cell neurons to $\mathrm{H}_{2} \mathrm{O}_{2}$, we examined the effect of various concentrations. Previous reports, using both vertebrate and invertebrate neurons, used a range of $\mathrm{H}_{2} \mathrm{O}_{2}$ from 1 to $3 \mathrm{mM}$, which did not cause damage in the short-term (Chen et al., 2001; Chang et al., 2003; Olah et al., 2009; Lee et al., 2011,
A

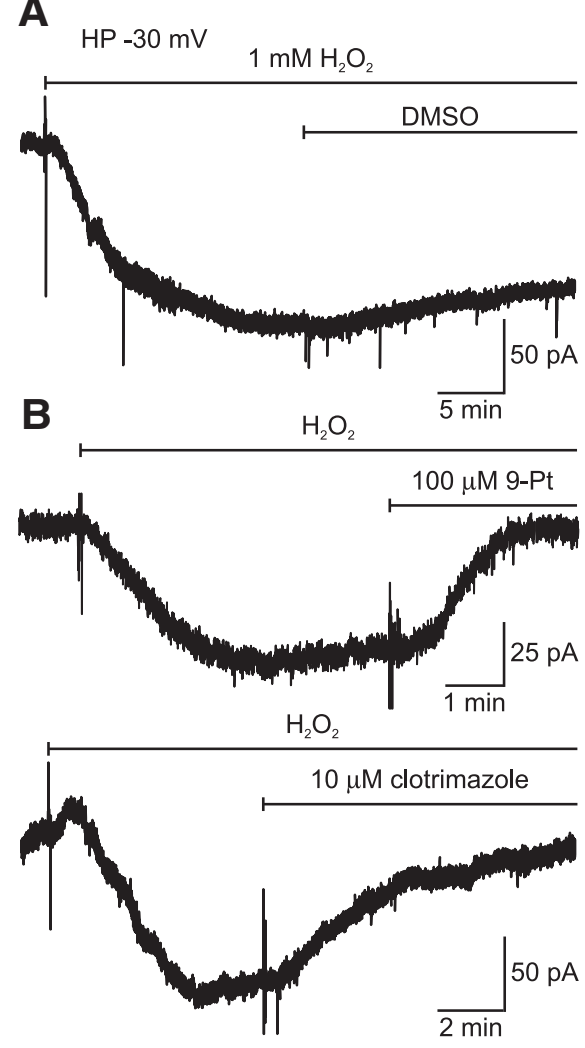

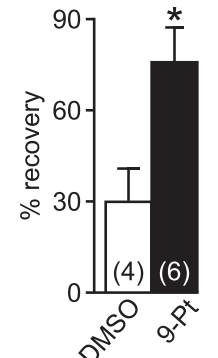

D

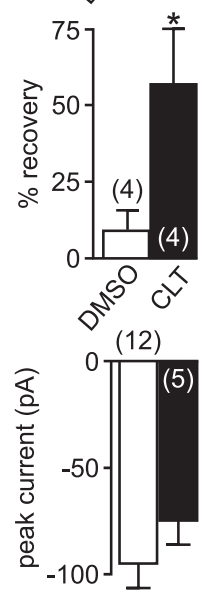

$\square \mathrm{H}_{2} \mathrm{O}_{2}$

$\mathrm{H}_{2} \mathrm{O}_{2}$ in $10 \mu \mathrm{M}$ SKF-96365

Figure 5. The pharmacology of the $\mathrm{H}_{2} \mathrm{O}_{2}$-induced current is consistent with a cation channel. $A$, Whole-cell voltage-clamp recording from a cultured bag cell neuron in $\mathrm{nASW}$ at $-30 \mathrm{mV}$ using $\mathrm{Cs}^{+}$-Asp-based intracellular saline shows an inward current in response to $1 \mathrm{~mm} \mathrm{H}_{2} \mathrm{O}_{2}$ (at bar). Bath-application of $0.1 \%$ (v/v) DMSO (vehicle, at second bar) at the peak of the response fails to alter the normal recovery of the current. $\boldsymbol{B}$, Delivery of $100 \mu \mathrm{m} 9-\mathrm{Pt}$ (top) or $10 \mu \mathrm{m}$ clotrimazole (bottom) at the peak of the response markedly inhibits the ongoing $1 \mathrm{~mm} \mathrm{H}_{2} \mathrm{O}_{2}-$ induced current. $\boldsymbol{C}, \boldsymbol{D}$, Summary graphs show both 9-Pt and clotrimazole significantly increase the percent recovery of the $\mathrm{H}_{2} \mathrm{O}_{2}$-induced current to $76.0 \pm 11.4 \%$ and $56.5 \pm 14.1 \%$, respectively, calculated by comparing the baseline (before $\mathrm{H}_{2} \mathrm{O}_{2}$ bath-application) and the steadystate current at the end of the trace $\left(t_{(8)}=2.743 ;{ }^{*} p=0.0253,9-\mathrm{Pt}, t_{(6)}=3.183 ;{ }^{*} p=\right.$ 0.0190 , clotrimazole, both unpaired Student's $t$ test). $E$, Group data of the $\mathrm{H}_{2} \mathrm{O}_{2}$-induced current in control vs neurons pretreated with $10 \mu \mathrm{M}$ SKF-96365. In contrast to $1 \mathrm{~mm} \mathrm{H}_{2} \mathrm{O}_{2}$ alone (93.4 \pm $11.4 \mathrm{pA})$, the presence of $10 \mu \mathrm{M}$ SKF- $96365(73.3 \pm 11.2 \mathrm{pA})$ does not significantly reduce the response $\left(U_{(5,12)}=21.0 ; p=0.3827 \mathrm{H}_{2} \mathrm{O}_{2}\right.$ vs $\mathrm{H}_{2} \mathrm{O}_{2}$ in SKF-96365; Mann-Whitney $U$ test $)$.

2013; Ohashi et al., 2016). Additionally, limitations on membrane permeability and intracellular scavenging suggests that the $\mathrm{H}_{2} \mathrm{O}_{2}$ concentration inside a cell is at least tenfold (perhaps even 650 -fold) less than the concentration of extracellularly applied $\mathrm{H}_{2} \mathrm{O}_{2}$ (Antunes et al., 2000; Miller et al., 2007; Huang and Sikes, 2014).

Because the $\mathrm{H}_{2} \mathrm{O}_{2}$-induced current was rather small at -60 $\mathrm{mV}$, and the holding current was often not entirely stable at 0 $\mathrm{mV}$, we chose to examine the response at $-30 \mathrm{mV}$ in subsequent recordings. This provided a more uniform $\mathrm{H}_{2} \mathrm{O}_{2}$-induced current with a reasonably stable baseline. Cultured bag cell neurons were whole-cell voltage-clamped in nASW using a Cs ${ }^{+}$-Aspbased intracellular saline to block $\mathrm{K}^{+}$channels and further improve resolution at this somewhat depolarized potential (Colmers et al., 1982; see Materials and Methods, Whole-cell voltageclamp and current-clamp recording from cultured bag cell neurons). $\mathrm{H}_{2} \mathrm{O}_{2}$ was tested at $30 \mu \mathrm{M}, 100 \mu \mathrm{M}, 300 \mu \mathrm{M}$, and $1 \mathrm{~mm}$ $(n=5,8,6,7)$. The resulting inward current was concentrationdependent, with a threshold of $100 \mu \mathrm{M}$ and the largest response at $1 \mathrm{~mm}$ (Fig. 2A,B). Fitting the concentration-response relation- 
ship with a four-parameter dose-response equation yielded an apparent $\mathrm{EC}_{50}$ of $14.2 \mathrm{~mm}$ with a Hill slope of 0.64 . If this was due to an agonist-type mechanism, it would be expected that the $\mathrm{H}_{2} \mathrm{O}_{2}$-induced current would recover following drug removal. When the $\mathrm{H}_{2} \mathrm{O}_{2}$-containing nASW superfusing over the soma was replaced with nASW alone, shortly after the $\mathrm{H}_{2} \mathrm{O}_{2}$-induced current reached peak, it recovered by $\sim 75 \%$ ( $n=4$; Fig. $2 C$, inset).

\section{The $\mathrm{H}_{2} \mathrm{O}_{2}$-induced current is consistent with the opening of a nonselective cation channel}

To verify channel opening, the membrane conductance was examined before and after $\mathrm{H}_{2} \mathrm{O}_{2}$ application, by delivering a $200 \mathrm{~ms}$ step to $-40 \mathrm{mV}$ from a holding potential of $-30 \mathrm{mV}$ under voltage-clamp (Fig. $3 A$, middle). A first step was delivered after a 15 min dialysis period, while a second step was given $\sim 90 \mathrm{~s}$ after that, right before $1 \mathrm{mM} \mathrm{H}_{2} \mathrm{O}_{2}$ superfusion, and a third step was performed at the peak of the $\mathrm{H}_{2} \mathrm{O}_{2}$ response (Fig. $3 \mathrm{~A}$, top). The ratios of the current from the second step (just before $\mathrm{H}_{2} \mathrm{O}_{2}$ ) versus the first step (Fig. 3B, control 2/1), and the third step (at the peak of $\mathrm{H}_{2} \mathrm{O}_{2}$ response) versus second step (Fig. $3 B, \mathrm{H}_{2} \mathrm{O}_{2}$ $3 / 2$ ) were taken to ascertain the change in conductance. The period preceding $\mathrm{H}_{2} \mathrm{O}_{2}$ presented essentially no change in conductance $(\sim 0.99$-fold $)$; however, the conductance change at the peak of the $\mathrm{H}_{2} \mathrm{O}_{2}$ response was significantly larger (by $\sim 1.75$-fold), in agreement with channel opening $(n=8$; Fig. $3 A$, bottom, $B)$.

We next characterized the ionic basis of the current. The permeability of $\mathrm{Na}^{+}$and $\mathrm{Ca}^{2+}$ was studied by replacing extracellular $\mathrm{Na}^{+}$with NMDG and/or $\mathrm{Ca}^{2+}$ with $\mathrm{Mg}^{2+}$ (see Materials and Methods, Whole-cell voltage-clamp). Compared with nASW as control $(n=11)$, the $\mathrm{H}_{2} \mathrm{O}_{2}$-induced current was reduced by $\sim 87 \%$ in $\mathrm{Ca}^{2+}$-free $(n=12), \sim 95 \%$ in $\mathrm{Na}^{+}$-free $(n=6)$, and was almost absent in $\mathrm{Na}^{+} / \mathrm{Ca}^{2+}$-free $(n=8)$ extracellular saline (Fig. 4A), suggesting that $\mathrm{H}_{2} \mathrm{O}_{2}$ acts on a nonselective cation conductance. On average, the observed decreases in current were significant versus control (Fig. $4 B$ ).

Ion substitution was also used to investigate the reversal potential of the $\mathrm{H}_{2} \mathrm{O}_{2}$-induced current. Specifically, a $5 \mathrm{~s}$ ramp from -60 to $+60 \mathrm{mV}$ was delivered under voltage-clamp from a holding potential of $-30 \mathrm{mV}$ (Fig. $4 \mathrm{C}$ ). The ramp was given twice, i.e., right before $\mathrm{H}_{2} \mathrm{O}_{2}$ application, and again at the peak of the $\mathrm{H}_{2} \mathrm{O}_{2}$ response. A difference current was then calculated by subtracting the first ramp-induced current from the second ramp-induced current. In nASW, the difference current was nonlinear (inward between $\sim-30$ and $\sim+30 \mathrm{mV}$ ), voltage-dependent, and reversed at $\sim+30 \mathrm{mV}(n=10$; Fig. $4 C)$. However, in the absence of extracellular $\mathrm{Ca}^{2+}$, or $\mathrm{Na}^{+}$, or $\mathrm{Na}^{+} / \mathrm{Ca}^{2+}$, the difference currents flattened out (Fig. $4 C$, top insets). Moreover, the reversal potential was significantly left-shifted in $\mathrm{Ca}^{2+}$-free $(\sim-8 \mathrm{mV}$; $n=15), \mathrm{Na}^{+}$-free $(\sim-11 \mathrm{mV} ; n=6)$, or $\mathrm{Na}^{+} / \mathrm{Ca}^{2+}$-free saline $(\sim-10 \mathrm{mV} ; n=10)$, as expected for a nonselective cation conductance (Fig. 4D).

\section{The pharmacology of the $\mathrm{H}_{2} \mathrm{O}_{2}$-induced current is also consistent with a cation channel}

Because the ion substitution and reversal potential results suggested a nonselective cation channel, we subsequently tested known cation channel blockers. In particular, 9-Pt, a purported transient receptor potential (TRP) cation channel melastatin subfamily isoform 4-specific inhibitor (Grand et al., 2008; Guinamard et al., 2014), clotrimazole, a general cation channel blocker known to prevent $\mathrm{H}_{2} \mathrm{O}_{2}$-induced currents in striatal and hippocampal neurons (Hill et al., 2004; Olah et al., 2009), and
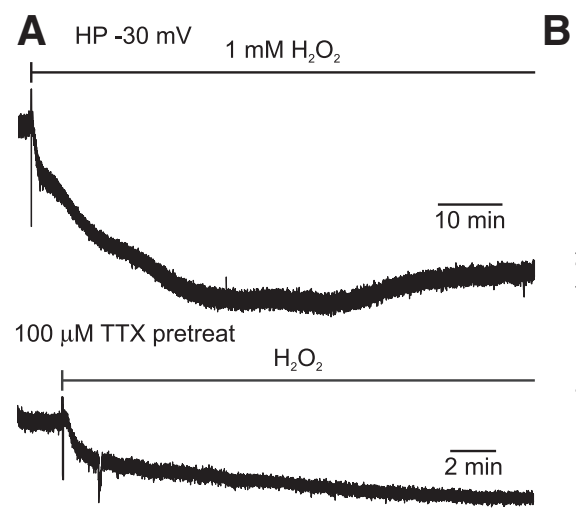

$300 \mu \mathrm{M}$ TTX pretreat
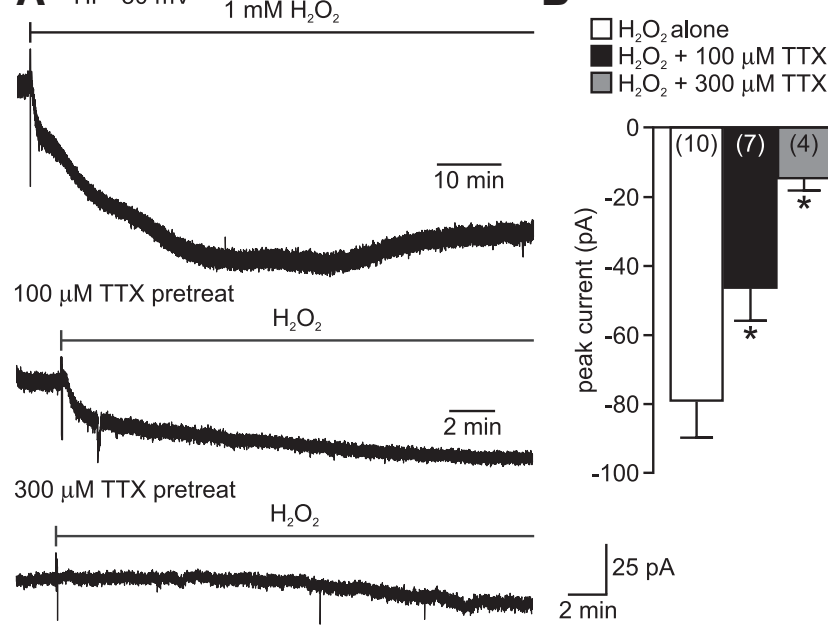

Figure 6. The $\mathrm{H}_{2} \mathrm{O}_{2}$-induced current is reduced by tetrodotoxin. $A$, Current responses to $1 \mathrm{~mm}$ $\mathrm{H}_{2} \mathrm{O}_{2}$ (at bar) of separate cultured bag cell neurons whole-cell voltage-clamped at $-30 \mathrm{mV}$ in $\mathrm{nASW}$ with $\mathrm{Cs}^{+}$-based intracellular saline. Compared with control (top), a 30 min pretreatment with $100 \mu \mathrm{M}$ TTX (middle) noticeably reduces the $\mathrm{H}_{2} \mathrm{O}_{2}$-induced current, while $300 \mu \mathrm{m}$, TTX (bottom) almost eliminates the response. Ordinate applies to all traces. $\boldsymbol{B}$, Group data of the $\mathrm{H}_{2} \mathrm{O}_{2}$-induced current in 100 or $300 \mu \mathrm{M}$ TTX vs control. Compared with $1 \mathrm{~mm} \mathrm{H}_{2} \mathrm{O}_{2}$ alone (79.9 \pm $7.7 \mathrm{pA})$, the presence of $100 \mu \mathrm{M}(47.1 \pm 9.4 \mathrm{pA})$ or $300 \mu \mathrm{M}$ TTX $(15.4 \pm 3.6 \mathrm{pA})$ significantly reduces the response $\left(F_{(2,18)}=12.570 ; p=0.0004\right.$ ordinary ANOVA, ${ }^{*} p<0.05 \mathrm{H}_{2} \mathrm{O}_{2}$ vs $\mathrm{H}_{2} \mathrm{O}_{2}$ post $100 \mu \mathrm{M}$ TTX; ${ }^{*} p<0.01 \mathrm{H}_{2} \mathrm{O}_{2}$ vs $\mathrm{H}_{2} \mathrm{O}_{2}$ post $300 \mu \mathrm{M}$ TTX, Dunnett multiple-comparisons test).

SKF-96365, which is often reported as a TRP channel canonical subfamily antagonist (Zhu et al., 1998), were used. Either 9-phenanthrol or clotrimazole were given at the peak of the response to $1 \mathrm{mM} \mathrm{H}_{2} \mathrm{O}_{2}$, the prediction being that a blocker would inhibit the channel and, compared with the vehicle (DMSO), increase the percent-recovery of the current (see Materials and Methods, Analysis). Whereas DMSO application (the vehicle; $n=4,4)$ resulted in $10-30 \%$ recovery (Fig. $5 A, C$ ), introducing $100 \mu \mathrm{M} 9$-phenanthrol $(n=6)$ or $10 \mu \mathrm{M}$ clotrimazole $(n=4$; Fig. $5 B$, top, bottom), significantly increased the percent-recovery of the $\mathrm{H}_{2} \mathrm{O}_{2}$-induced current to $\sim 75$ and $\sim 55 \%$, respectively (Fig. $5 C, D)$. For SKF-96365, $10 \mu \mathrm{M}$ of the blocker was bath-applied 10 min before $1 \mathrm{mM} \mathrm{H}_{2} \mathrm{O}_{2}$ delivery; however, compared with $\mathrm{H}_{2} \mathrm{O}_{2}$ alone, the presence of SKF-96365 did not significantly alter the current (Fig. 5E).

Some TRPC channels are sensitive to changes in glucose concentration; for example, Lee et al. (2015b) reported that low glucose enhances neuronal TRPC channels, likely through a pathway involving the triggering of adenosine monophosphateactivated protein kinase. In the present study, the extracellular saline normally did not contain glucose (see Materials and Methods, Whole-cell voltage-clamp and current-clamp recording from cultured bag cell neurons); thus, we examined whether introducing $1 \mathrm{~mm}$ extracellular glucose beforehand would impact the $\mathrm{H}_{2} \mathrm{O}_{2}$-induced current. The presence of this low glucose concentration did not significantly alter the response to $1 \mathrm{mM} \mathrm{H}_{2} \mathrm{O}_{2}$ $\left(\mathrm{H}_{2} \mathrm{O}_{2}\right.$ alone: $65.3 \pm 16.0 \mathrm{pA}, n=4$ vs $\mathrm{H}_{2} \mathrm{O}_{2}$ in glucose: $68.0 \pm$ $16.7 \mathrm{pA}, n=4$; $t_{(6)}=0.1189 ; p=0.9093$, unpaired Student's $t$ test). Because the $\mathrm{Cs}^{+}$-based intracellular saline used for most whole-cell experiments contained $11 \mathrm{~mm}$ glucose, we also performed a control for this intracellular addition of glucose via the pipette by recording the $\mathrm{H}_{2} \mathrm{O}_{2}$-induced current using sharpelectrode voltage-clamp. Neurons were impaled with a sharpelectrode (which does not permit appreciable exchange with the 
cytosol) and held at $-30 \mathrm{mV}$ (see Materials and Methods, Sharp-electrode recording from bag cell neurons in culture and isolated clusters). We found that the current under the sharp-electrode configuration $(140 \pm 39.2 \mathrm{pA} ; n=6)$ was not significantly different from parallel controls performed using whole-cell pipettes containing $\mathrm{Cs}^{+}$-based intracellular saline with glucose $\left(112 \pm 32.2 \mathrm{pA} ; n=5 ; t_{(9)}=\right.$ $0.5390 ; p=0.6030$, unpaired Student's $t$ test).

Our data suggest that the $\mathrm{H}_{2} \mathrm{O}_{2}$ induced current is mediated by a conductance similar to the voltage-dependent nonselective cation channel characterized in bag cell neurons by Wilson et al. (1996). Those authors reported that this channel was blocked by relatively high concentrations $(80-100 \mu \mathrm{M})$ of the classical $\mathrm{Na}^{+}$ channel antagonist, TTX (Narahashi et al., 1964). Thus, to confirm any similarity, we initially bath-applied $100 \mu \mathrm{M}$ TTX at the peak of $\mathrm{H}_{2} \mathrm{O}_{2}$-induced current. However, we observed no difference in percent-recovery of the response in the presence $(n=5 ; 41.6 \pm 7.7 \%)$ or absence of TTX $\left(n=6 ; 41.2 \pm 8.6 \% ; t_{(9)}=\right.$ 0.03097; $p=0.9760$, unpaired Student's $t$ test). TTX has one primary alcohol and three secondary alcohol functional groups. Chicheportiche et al. (1980) showed that the secondary alcohols can be oxidized, resulting in inactive toxin. Thus, in the present study TTX may have been oxidized upon bath-application in the presence of $\mathrm{H}_{2} \mathrm{O}_{2}$. To avoid this, we opted for pretreatment with TTX and delivering $\mathrm{H}_{2} \mathrm{O}_{2}$ afterward. Compared with the control $\mathrm{H}_{2} \mathrm{O}_{2}$-induced current $(n=10)$, a 30 min pretreatment with $100 \mu \mathrm{M}$ TTX $(n=$ 7 ) reduced the response by $\sim 40 \%$ (Fig. $6 A$, top, middle). Moreover, a further decrease in the response, to $\sim 15 \%$ of control, was seen with $300 \mu \mathrm{M}$ TTX pretreatment $(n=4$; Fig. $6 A$, bottom). The presence of 100 or $300 \mu \mathrm{M}$ TTX significantly reduced the $\mathrm{H}_{2} \mathrm{O}_{2}$ response versus control (Fig. 6B).

\section{The $\mathrm{H}_{2} \mathrm{O}_{2}$-induced current is boosted by preventing oxidation and attenuated by promoting reduction}

Glutathione peroxidase is a cytosolic enzyme that catalyzes the reduction of $\mathrm{H}_{2} \mathrm{O}_{2}$ to $\mathrm{H}_{2} \mathrm{O}$, and the concomitant oxidation of glutathione (Jones et al., 1981). Mercaptosuccinate inhibits glutathione peroxidase, thus preventing $\mathrm{H}_{2} \mathrm{O}_{2}$ reduction (Dringen et al., 1998); hence, we hypothesized that delivering mercaptosuccinate for $\sim 10$ min before $\mathrm{H}_{2} \mathrm{O}_{2}$ would increase the response. Bath-application of $1 \mathrm{~mm}$ mercaptosuccinate alone had little to no effect on the holding current ( $n=10$; Fig. $7 A$, top). As expected, introducing $1 \mathrm{mM} \mathrm{H}_{2} \mathrm{O}_{2}$ on its own $(n=6)$ produced an inward current; in addition, this was significantly enhanced by $\sim 50 \%$ in the presence of mercaptosuccinate $(n=8$; Fig. $7 A$,
C

E

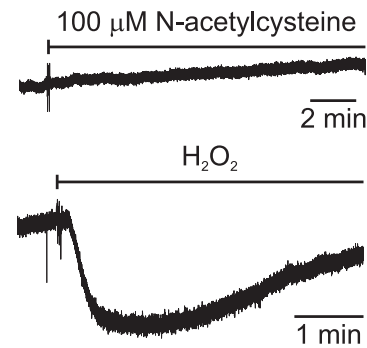

in NAC

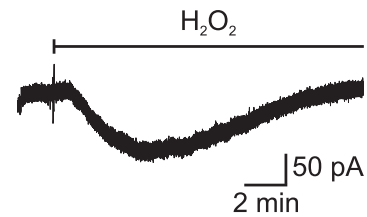

in DTT

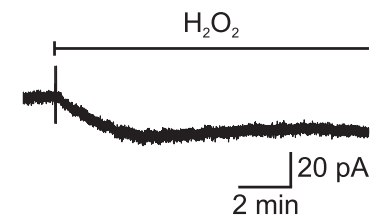

D $\square \mathrm{NAC}$

$\mathrm{H}_{2} \mathrm{O}_{2}$
$\square \mathrm{H}_{2} \mathrm{O}_{2}$ in NAC

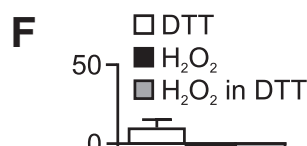

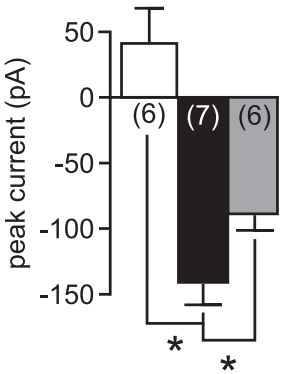

Figure 7. The $\mathrm{H}_{2} \mathrm{O}_{2}$-induced current is enhanced by mercaptosuccinate and reduced by $\mathrm{N}$-acetylcysteine or dithiothreitol. Cultured bag cell neurons are bathed in nASW and whole-cell voltage-clamped at $-30 \mathrm{mV}$ using $\mathrm{Cs}^{+}{ }^{+}$-based intracellular saline. (bottom). Ordinate applies to all traces. $\boldsymbol{B}$, Summary graph of peak mercaptosuccinate- and 50.879; $p<0.0001$, ordinary ANOVA; ${ }^{*} p<0.001$ mercapto vs $\mathrm{H}_{2} \mathrm{O}_{2} ;{ }^{*} p<0.05 \mathrm{H}_{2} \mathrm{O}_{2}$ vs $\mathrm{H}_{2} \mathrm{O}_{2}$ in mercapto, Tukey-Kramer multiple-comparisons test). $C$, Introducing $100 \mu \mathrm{m}$ NAC has only a nominal impact (top), whereas $1 \mathrm{~mm} \mathrm{H}_{2} \mathrm{O}_{2}$ generates an inward showing that compared with $\mathrm{N}$-acetylcysteine alone $(43.3 \pm 25.7 \mathrm{pA})$, the $\mathrm{H}_{2} \mathrm{O}_{2}$-induced current differs significantly with $(90.3 \pm$ $21.4 \mathrm{pA})$ and without $\mathrm{N}$-acetylcysteine $\left(148.0 \pm 16.0 \mathrm{pA} ; U_{(6,7)}=0 ;{ }^{*} p=0.0034 \mathrm{NAC} \mathrm{vs} \mathrm{H}_{2} \mathrm{O}_{2} ; U_{(6,7)}=5 ;{ }^{*} p=0.0221 \mathrm{H}_{2} \mathrm{O}_{2}\right.$ vs

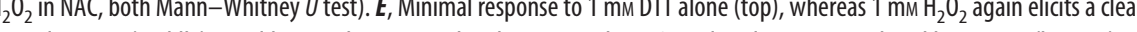
$9.6 \mathrm{pA})$ and without DTT $\left(155.0 \pm 13.2 \mathrm{pA} ; \mathrm{F}_{(2,15)}=73.831 ; p<0.0001\right.$, ordinary ANOVA; ${ }^{*} p<0.001 \mathrm{DTT}_{\text {vs }} \mathrm{H}_{2} \mathrm{O}_{2} ;{ }^{*} p<0.001$ $\mathrm{H}_{2} \mathrm{O}_{2}$ vs $\mathrm{H}_{2} \mathrm{O}_{2}$ in DTT, Tukey-Kramer multiple-comparisons test).

middle, bottom, $B$ ). To further examine the role of glutathione in moderating the $\mathrm{H}_{2} \mathrm{O}_{2}$-induced current, we initially exposed neurons to $100 \mu \mathrm{M}$ of $N$-acetylcysteine, which increases glutathione levels by elevating the intracellular concentration of the glutathione synthesis precursor, cysteine (Cotgreave et al., 1991). On its own, $\mathrm{N}$-acetylcysteine did not cause a change in current at $-30 \mathrm{mV}$ ( $n=6$; Fig. $7 C$, top); yet, delivery of $1 \mathrm{mM} \mathrm{H}_{2} \mathrm{O}_{2} \sim 10$ min after $N$-acetylcysteine $(n=6)$ evoked an inward current which was significantly reduced by $\sim 40 \%$ when contrasted with the response to just $\mathrm{H}_{2} \mathrm{O}_{2}(n=7$; Fig. $7 C$, middle, bottom, $D)$.

To test whether cation channel activation by $\mathrm{H}_{2} \mathrm{O}_{2}$ occurs via oxidation of sulfhydryl groups, we used DTT, a reducing agent that maintains thiol groups on amino acids, such as Cys, in the reduced state (Cleland, 1964). Application of DTT alone did not 


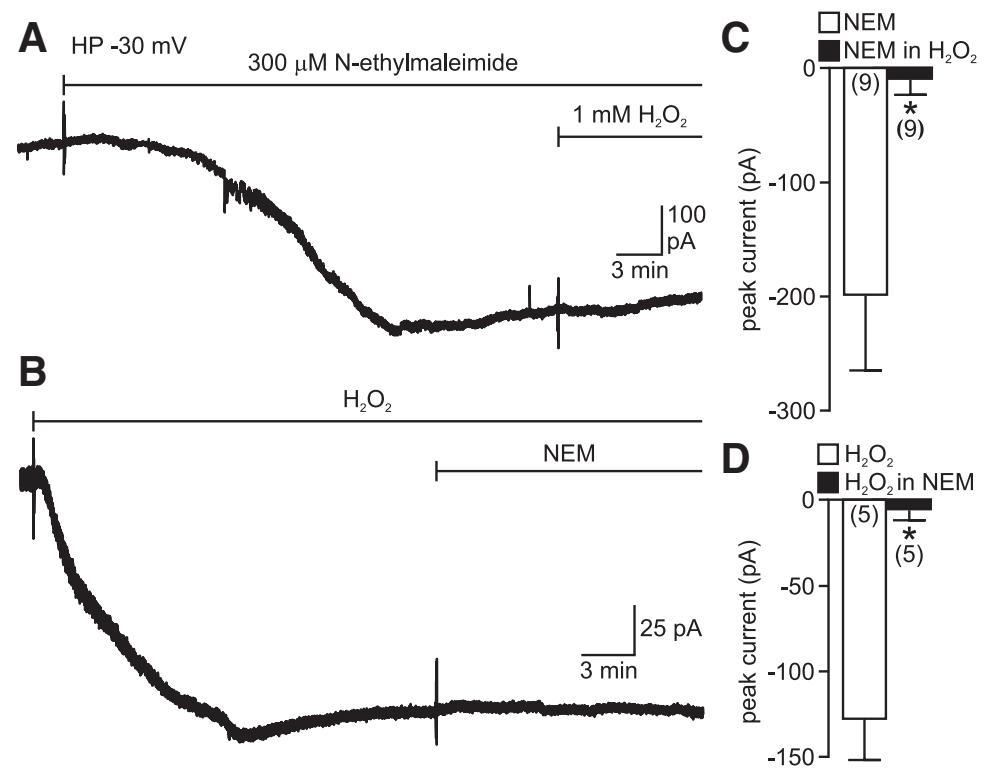

Figure 8. NEM- and $\mathrm{H}_{2} \mathrm{O}_{2}$-induced currents are occlusive. Representative response to $300 \mu \mathrm{M} \mathrm{NEM} \mathrm{or} 1 \mathrm{~mm} \mathrm{H}_{2} \mathrm{O}_{2}$ of different cultured bag cell neurons whole-cell voltage-clamped at $-30 \mathrm{mV}$ in nASW with $\mathrm{Cs}^{+}$-based intracellular saline. $\boldsymbol{A}$, Bathapplication (at bar) of NEM evokes a prominent inward current. $\mathrm{Yet}_{1} \mathrm{H}_{2} \mathrm{O}_{2}$ (at second bar) in the presence of NEM, yield little further change. $\boldsymbol{B}$, Delivery of $\mathrm{H}_{2} \mathrm{O}_{2}$ elicits a typical inward current in a separate neuron, but there is no obvious current when NEM is applied in the presence of $\mathrm{H}_{2} \mathrm{O}_{2}$. C, D, Summary data demonstrates a significant difference between the NEM-elicited current (201.0 \pm 65.5 $\mathrm{pA})$ and the $\mathrm{H}_{2} \mathrm{O}_{2}$-induced current post-NEM $\left(11.7 \pm 13.1 \mathrm{pA} ; U_{(9,9)}=7.0 ;{ }^{*} p=0.0019\right.$, Mann-Whitney $U$ test). Similarly, there is a significant difference between the $\mathrm{H}_{2} \mathrm{O}_{2}$-induced current $(129.6 \pm 24.5 \mathrm{pA})$ and the NEM-elicited current post- $\mathrm{H}_{2} \mathrm{O}_{2}(6.3 \pm 5.9$ $\mathrm{pA} ;\left(t_{(4)}=4.90 ;{ }^{*} p=0.008\right.$, unpaired Student's $t$ test, Welch corrected). Note, there is no statistical difference between the initial current produced by NEM and $\mathrm{H}_{2} \mathrm{O}_{2}$ (white bars; $t_{(9)}=1.022 ; p=0.3337$, unpaired Student's $t$ test, Welch corrected); as well, the $\mathrm{NEM}$ - and the $\mathrm{H}_{2} \mathrm{O}_{2}$-induced currents in the presence of $\mathrm{H}_{2} \mathrm{O}_{2}$ and NEM, respectively, are not statistically different (black bars; $U_{(5,9)}$ $=14.0 ; p=0.2977$, Mann-Whitney $U$ test $)$.

elicit a current at $-30 \mathrm{mV}(n=6$; Fig. $7 E$, top). However, in the presence of DTT, the response to $1 \mathrm{mM} \mathrm{H}_{2} \mathrm{O}_{2}$ was obviously decreased compared with the delivery of $\mathrm{H}_{2} \mathrm{O}_{2}$ alone $(n=6$; Fig. $7 E$, middle, bottom). The $\mathrm{H}_{2} \mathrm{O}_{2}$ current was reduced by $\sim 70 \%$ and this drop was significant (Fig. $7 F$ ).

NEM- and $\mathrm{H}_{2} \mathrm{O}_{2}$-induced currents are occlusive

The ability of DTT to prevent $\mathrm{H}_{2} \mathrm{O}_{2}$ from activating the current suggests that $\mathrm{H}_{2} \mathrm{O}_{2}$ may gate the cation channel by direct oxidation of sulfur-containing amino acids, in particular, Cys and/or Met residues in the channel or an associated protein(s) (Hoshi and Heinemann, 2001). NEM is a sulfydryl alkylating agent (Jakobs et al., 1982) that can remove hydrogen from thiol side chains and replace it with a carbon-sulfur bond, potentially minimizing $\mathrm{H}_{2} \mathrm{O}_{2}$-mediated oxidation (Gregory, 1955). Therefore, we tested the effects of NEM on both membrane current itself and the $\mathrm{H}_{2} \mathrm{O}_{2}$-induced current. Bath-application of $300 \mu \mathrm{M}$ NEM elicited an $\sim 200 \mathrm{pA}$ inward current at $-30 \mathrm{mV}(n=9)$, with the subsequent addition of $1 \mathrm{mM} \mathrm{H}_{2} \mathrm{O}_{2}$ evoking only a small response of $\sim 12$ pA ( $n=9$; Fig. $8 A$ ). Similarly, when $\mathrm{H}_{2} \mathrm{O}_{2}$ was added to the bath first, it brought about a typical inward current $(n=5)$, whereas delivery of NEM afterward again caused little change $\left(n=5\right.$; Fig. $8 B$ ). The currents induced by $\mathrm{H}_{2} \mathrm{O}_{2}$ and NEM, respectively, were not significantly different on average (Fig. $8 C, D$, two white bars); moreover, the two currents occluded one another (Fig. 8C,D, two black bars).

\section{$\mathrm{H}_{2} \mathrm{O}_{2}$ depolarizes and induces robust action potential firing}

Given that $\mathrm{H}_{2} \mathrm{O}_{2}$ application elicits an inward current, we sought to determine the impact of introducing $\mathrm{H}_{2} \mathrm{O}_{2}$ on cultured bag cell neuron membrane potential. This was performed using whole- cell current-clamp in nASW with the $\mathrm{K}^{+}$based intracellular saline in the pipette. $\mathrm{H}_{2} \mathrm{O}_{2}$ was tested at both $-40 \mathrm{mV}$, the approximate membrane potential during the afterdischarge, and $-60 \mathrm{mV}$, the approximate membrane potential before or at the start of the afterdischarge (Kupfermann and Kandel, 1970; Kaczmarek et al., 1982). Bath application of $100 \mu \mathrm{M} \mathrm{H}_{2} \mathrm{O}_{2}$ induced a depolarization of $\sim 7$ and $\sim 14$ $\mathrm{mV}$ from $-40(n=7)$ and $-60 \mathrm{mV}(n=$ $5)$, respectively, versus $\mathrm{H}_{2} \mathrm{O}$ as control at $-40 \mathrm{mV}(n=5)$ or $-60 \mathrm{mV}(n=5)$, which had no obvious effect (Fig. 9A, $B$ ). In no case did $100 \mu \mathrm{M} \mathrm{H} \mathrm{H}_{2} \mathrm{O}_{2}$ cause the neuron to fire action potentials. However, $1 \mathrm{mM} \mathrm{H}_{2} \mathrm{O}_{2}$ not only depolarized the membrane, by $\sim 11 \mathrm{mV}$ for $-40 \mathrm{mV}(n=$ 5 ) and $\sim 22 \mathrm{mV}$ for $-60 \mathrm{mV}(n=5)$, but consistently evoked a burst of spikes (Fig. $9 C)$. Compared with $\mathrm{H}_{2} \mathrm{O}$, the magnitudes of the responses were significant for both -40 and $-60 \mathrm{mV}$ (Fig. 9D). As for the action potential firing, it lasted for $\sim 8$ $\min$ at $-40 \mathrm{mV}$ and $\sim 7 \mathrm{~min}$ at $-60 \mathrm{mV}$ with the latency of $\sim 3$ min and frequency of $\sim 1 \mathrm{~Hz}$ at both voltages (Fig. $9 E$ ).

Knowing that the $\mathrm{H}_{2} \mathrm{O}_{2}$-induced current is blocked by 9-phenanthrol, clotrimazole, or TTX, we next investigated whether these blockers altered the depolarization to $1 \mathrm{mM} \mathrm{H}_{2} \mathrm{O}_{2}$ from $-40 \mathrm{mV}$. As expected, $1 \mathrm{~mm} \mathrm{H}_{2} \mathrm{O}_{2}(n=18)$ elicited a depolarization of $\sim 9$ $\mathrm{mV}$ and action potential firing of $\sim 1 \mathrm{~Hz}$ that lasted for $\sim 12 \mathrm{~min}$ (Fig. $10 A$, top, $B$ ). This response was essentially eliminated by a 20 min pretreatment with either $10 \mu \mathrm{M}$ clotrimazole $(n=6 ;-2.8 \pm$ $1.4 \mathrm{mV}$ ) or $100 \mu \mathrm{M}$ 9-phenanthrol $(n=6 ; 4.0 \pm 2.2 \mathrm{mV}$; Fig. $10 \mathrm{~A}$, middle). As for TTX $(n=4)$, incubating in $300 \mu \mathrm{M}$ did not prevent the depolarization altogether (Fig. 10B, top); instead, it significantly reduced the firing frequency to $\sim 0.5 \mathrm{~Hz}$ and the duration of spiking to $\sim 3 \mathrm{~min}$ (Fig. $10 A$, bottom, $B$, middle, bottom).

\section{$\mathrm{H}_{2} \mathrm{O}_{2}$ depolarizes bag cell neurons and initiates an afterdischarge in desheathed clusters}

Because $\mathrm{H}_{2} \mathrm{O}_{2}$ both gates a cation channel and causes bursting in cultured bag cell neurons, we sought to ascertain whether $\mathrm{H}_{2} \mathrm{O}_{2}$ can produce afterdischarge-like responses from the bag cell neuron cluster itself. To begin with, $1-10 \mathrm{mM} \mathrm{H}_{2} \mathrm{O}_{2}$ was bath-applied to the entire abdominal ganglion while recording extracellularly from one of the two intact bag cell neuron clusters (see Materials and Methods, Ensemble extracellular recording from the intact bag cell neuron cluster). However, this failed to bring about an afterdischarge nor did $\mathrm{H}_{2} \mathrm{O}_{2}$ affect the ability of synaptic input to evoke an afterdischarge, as subsequent stimulation of the pleuroabdominal connective resulted in normal afterdischarges that were of the same duration $(n=4 ; 57.8 \pm 12.6 \mathrm{~min})$ compared with those elicited in ganglia not exposed to $\mathrm{H}_{2} \mathrm{O}_{2}(n=7 ; 44.4 \pm$ $14.1 \mathrm{~min} ; t_{(9)}=0.6349 ; p=0.5413$, unpaired Student's $t$ test).

It is possible that the sheath surrounding the cluster hindered diffusion of $\mathrm{H}_{2} \mathrm{O}_{2}$ to the bag cell neurons and/or antioxidant mechanisms present either in the sheath cells or the extracellular space reduced the exogenous $\mathrm{H}_{2} \mathrm{O}_{2}$. Therefore, to demonstrate 
that direct delivery of $\mathrm{H}_{2} \mathrm{O}_{2}$ to the cluster can elicit bursting, the connective sheath was removed and the entire bag cell neuron cluster was isolated from the abdominal ganglion and placed in a culture dish. Sharp-electrode recordings were then made within the cluster from individual bag cell neurons initially current-clamped at $-60 \mathrm{mV}$ (see Materials and Methods, Sharp-electrode recording from bag cell neurons in culture and isolated clusters). Still, bath-applying $10 \mathrm{~mm} \mathrm{H}_{2} \mathrm{O}_{2}$ alone resulted in a depolarization of just $\sim 10 \mathrm{mV}$ ( $n=5$; Fig. $11 C$, left, white bar), with only one of the five preparations exhibiting a 10.9 min burst of action potentials.

We speculated that $\mathrm{H}_{2} \mathrm{O}_{2}$ may need to work in concert with the known bag cell neuron input transmitter, ACh (White and Magoski, 2012). Previously, our lab showed that brief pressure-application of ACh to the isolated bag cell neuron cluster would initiate a transient depolarization in a given neuron, sometimes accompanied by afterdischarge-like spiking (White et al., 2018). Thus, in the present study, while again recording from a single bag cell neuron within the cluster, ACh was first pressure-ejected followed by the introduction of $\mathrm{H}_{2} \mathrm{O}_{2}$ (Fig. $11 \mathrm{~B}$, inset). In nine separate preparations, a $2 \mathrm{~s}$ pressureejection of $1 \mathrm{~mm}$ ACh to one side of the cluster caused depolarization of a bag cell neuron recorded on the other side, with a mean of $6.4 \pm 3.4 \mathrm{mV}$ (Fig. 11A). Moreover, bath-applying $10 \mathrm{mM} \mathrm{H}_{2} \mathrm{O}_{2}, 8.3 \pm$ 1.3 min later, evoked a burst within $\sim 3$ min, consisting of a depolarization of $\sim 25$ $\mathrm{mV}$ and spiking at $\sim 0.8 \mathrm{~Hz}$ for $\sim 6 \mathrm{~min}$ (Fig. $11 B, C$, black bars). In all nine clusters, administering $\mathrm{H}_{2} \mathrm{O}_{2}$ after ACh always led to spiking, as well as a significantly greater depolarization compared with the five clusters exposed to $\mathrm{H}_{2} \mathrm{O}_{2}$ alone (Fig. $11 C)$.

\section{Discussion}

$\mathrm{H}_{2} \mathrm{O}_{2}$ can oxidize DNA, lipids, or proteins (Halliwell, 1992; Gutteridge and Halliwell, 1992), which may bring about synaptic plasticity (Kamsler and Segal, 2004; Kishida and Klann, 2007) or gate ion channels (Avshalumov et al., 2007). For example, various cation currents in hippocampal, nigral, and striatal neurons are opened by $\mathrm{H}_{2} \mathrm{O}_{2}$ (Hill et al., 2006; Olah et al., 2009; Lee et al., 2013). The bag cell neuron afterdischarge is maintained by various nonselective cation channels. In the fast-phase, $\mathrm{Ca}^{2+}$ influx and release opens a voltage-independent cation channel, with a linear current/voltage relationship and an $\sim-40 \mathrm{mV}$ reversal potential (Hung and Magoski, 2007; Hickey et al., 2010). With the slow-phase, phospholipase C cleaves $\mathrm{PIP}_{2}$ into $\mathrm{IP}_{3}$ and DAG (Fink et al., 1988). DAG gates a second, voltageindependent cation channel, with a distinct pharmacology and reversal potential of $\sim-20 \mathrm{mV}$ (Sturgeon and Magoski, 2016).

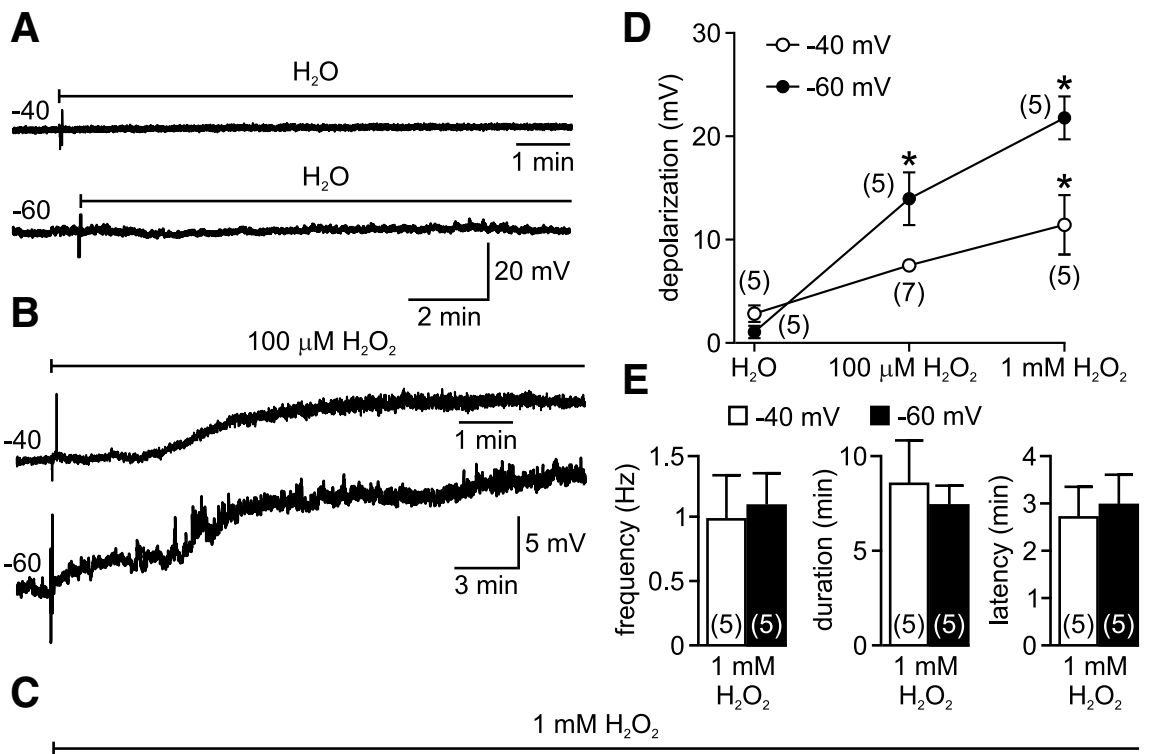

Figure 9. $\mathrm{H}_{2} \mathrm{O}_{2}$ depolarizes and induces robust action potential firing. $\boldsymbol{A}$, Separate cultured bag cell neurons are whole-cell current-clamped in nASW with $\mathrm{K}^{+}$-based intracellular saline and initially set to either -40 or $-60 \mathrm{mV}$ with bias current. Bath-application (at bar) of $\mathrm{H}_{2} \mathrm{O}(0.5 \% \mathrm{v} / \mathrm{v}$ ) at -40 (top) or $-60 \mathrm{mV}$ (bottom) does not affect membrane voltage. Ordinate applies to both traces. $\boldsymbol{B}$, Exposure to $100 \mu \mathrm{M} \mathrm{H}_{2} \mathrm{O}_{2}$ depolarizes two different neurons from both -40 (top) and -60 (bottom) mV, but

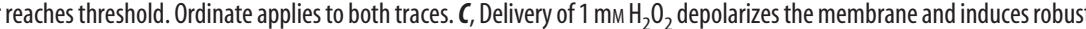
action potential firing from both -40 (top) and -60 (bottom) $\mathrm{mV}$ in separate cells. Ordinate applies to both traces. D, Summary graph indicating the average depolarizations from -40 (open circles) or -60 (closed circles) $\mathrm{mV}$. Compared with the response $\mathrm{mV}: 7.5 \pm 0.6 \mathrm{mV} ;-60 \mathrm{mV}: 14.0 \pm 2.6 \mathrm{mV})$ or $1 \mathrm{~mm} \mathrm{H}_{2} \mathrm{O}_{2}(-40 \mathrm{mV}: 11.4 \pm 2.9 ;-60 \mathrm{mV}: 21.8 \pm 2.1)$ is significantly different multiple-comparison's test; $-60 \mathrm{mV}: F_{(2,12)}=29.275 ; p<0.0001$, ordinary ANOVA; ${ }^{*} p<0.01 \mathrm{H}_{2} 0$ vs $100 \mu \mathrm{m} \mathrm{H}_{2} 0_{2},{ }^{*} p<0.001$ $\mathrm{H}_{2} \mathrm{O}$ v $1 \mathrm{~mm} \mathrm{H}_{2} \mathrm{O}_{2}$, Tukey-Kramer multiple-comparisons test). $\boldsymbol{E}$, Group data show no significant difference in the frequency $\left(t_{(8)}=\right.$ $0.2841 ; p=0.7835$, unpaired Student's $t$ test) or duration $\left(t_{(8)}=0.3884 ; p=0.7079\right.$, unpaired Student's $t$ test) of action potential firing from -40 versus $-60 \mathrm{mV}$ caused by $1 \mathrm{~mm} \mathrm{H}_{2} \mathrm{O}_{2}$. In addition, there is no significant difference in the latency, i.e., the time it takes for the neuron to start firing action potentials post- $\mathrm{H}_{2} \mathrm{O}_{2}$ delivery, between responses at $-40 \mathrm{mV}(2.8 \pm 0.6 \mathrm{mV})$ and $-60 \mathrm{mV}\left(3.0 \pm 0.6 \mathrm{mV} ; t_{(8)}=0.3001 ; p=0.7718\right.$, unpaired Student's $t$ test $)$.

This channel may be similar to TRPC3/6/7 channels, which are well established as being activated by DAG (Hofmann et al., 1999; Okada et al., 1999). DAG also activates PKC to mediate a number of afterdischarge-associated events (DeRiemer et al., 1984; Wayne et al., 1999; Groten and Magoski, 2015), including the regulation of a third cation channel that is voltage-dependent with a reversal potential $>+30 \mathrm{mV}$ (Wilson et al., 1996, 1998; Magoski and Kaczmarek, 2005; Gardam and Magoski, 2009; Sturgeon and Magoski, 2018). PKC also stimulates $\mathrm{H}_{2} \mathrm{O}_{2}$ production in bag cell neurons (Munnamalai et al., 2014), suggesting that $\mathrm{H}_{2} \mathrm{O}_{2}$ may be a signaling molecule during the afterdischarge.

We find that extracellular application of $\mathrm{H}_{2} \mathrm{O}_{2}$ elicits a prolonged voltage- and concentration-dependent inward current in 


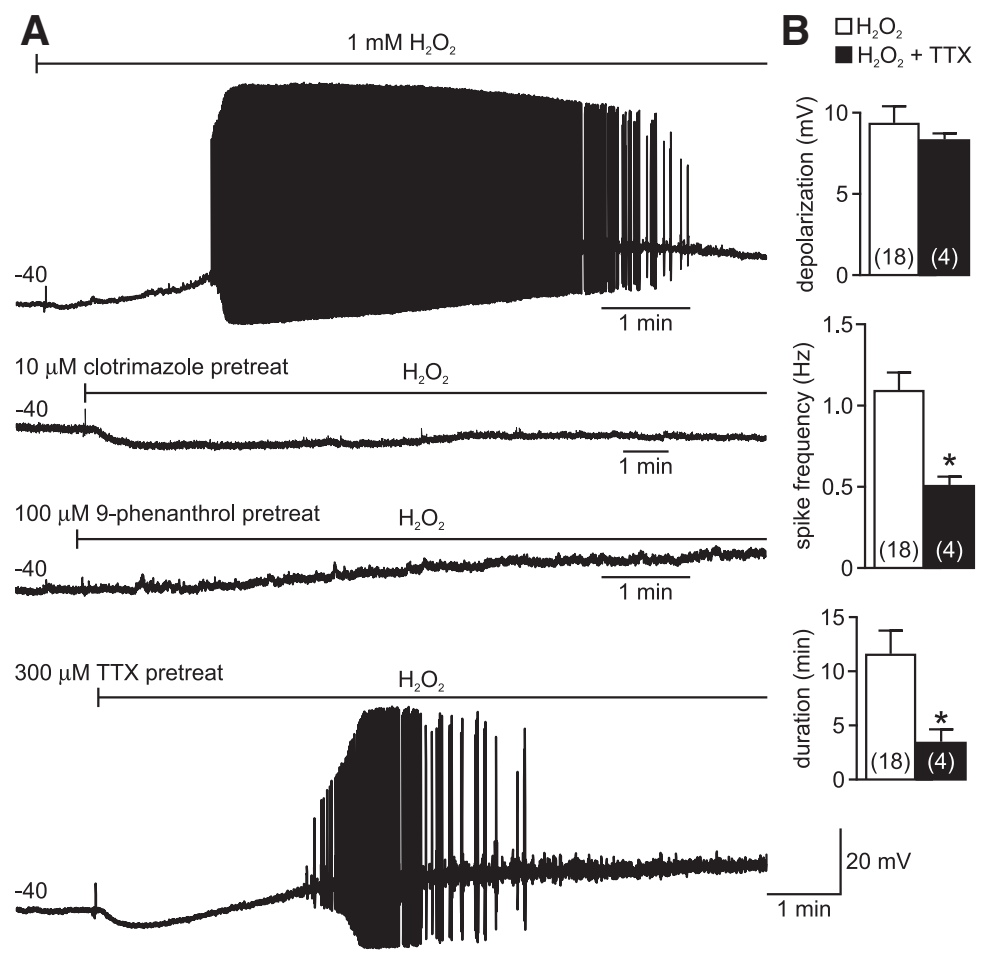

Figure 10. $\mathrm{H}_{2} \mathrm{O}_{2}$-evoked spiking is reduced by tetrodotoxin and prevented by 9-Pt or clotrimazole. Voltage responses to $1 \mathrm{~mm}$ $\mathrm{H}_{2} \mathrm{O}_{2}$ of different cultured bag cell neurons whole-cell current-clamped to $-40 \mathrm{mV}$ in nASW with $\mathrm{K}^{+}$-based intracellular saline after 20 min pretreatment with clotrimazole, 9-Pt, or TTX. A, Bath-application of $1 \mathrm{~mm} \mathrm{H}_{2} \mathrm{O}_{2}$ (at bar) induces robust action potential firing (top). However, a 20 min pretreatment with $10 \mu \mathrm{m}$ clotrimazole (upper middle) or $100 \mu \mathrm{m}$ 9-phenanthrol (lower middle) virtually eliminates the depolarization and prevents firing all together. Finally, after $20 \mathrm{~min}$ of $300 \mu \mathrm{m}$ TTX (bottom), introducing $\mathrm{H}_{2} \mathrm{O}_{2}$ still leads to membrane depolarization, but the duration and frequency of action potential firing is lessened. The ordinate applies to all traces. $\boldsymbol{B}$, Summary graph indicating the average $\mathrm{H}_{2} \mathrm{O}_{2}$-evoked depolarization (top) in the presence of $300 \mu \mathrm{M}$ TTX does not differ significantly from $1 \mathrm{~mm} \mathrm{H}_{2} \mathrm{O}_{2}$ alone $\left(U_{(4,18)}=32.0 ; p=0.7743\right.$, Mann-Whitney $U$ test). However, spike frequency (middle) and duration (bottom) are significantly reduced when TTX is in the bath (frequency: $U_{(4,18)}=6.0 ;{ }^{*} p=0.0120$; duration: $U_{(4,18)}=5.0 ;{ }^{*} p=0.0049$, both Mann-Whitney $U$ test $)$.

cultured bag cell neurons. The response is observed with as low as a $100 \mu \mathrm{M} \mathrm{H}_{2} \mathrm{O}_{2}$, although for consistency we primarily used $1 \mathrm{~mm}$. Previous reports involving both cultured Aplysia sensory neurons and various mammalian neurons in vitro or ex vivo use comparable amounts of $\mathrm{H}_{2} \mathrm{O}_{2}$ and, similar to our work, show channel gating but no obvious damage (Chen et al., 2001; Chang et al., 2003; Olah et al., 2009; Lee et al., 2011, 2013; Ohashi et al., 2016). Quite possibly, these concentrations are necessary because the fast consumption of $\mathrm{H}_{2} \mathrm{O}_{2}$ by intracellular antioxidant enzymes produces a high-extracellular to low-intracellular $\mathrm{H}_{2} \mathrm{O}_{2}$ gradient, estimated by some to be up to 650-fold (Huang and Sikes, 2014). Thus, it is plausible that $\mathrm{H}_{2} \mathrm{O}_{2}$ falls substantially as it is scavenged once diffusing across the bag cell neuron membrane.

The increase in membrane conductance during the $\mathrm{H}_{2} \mathrm{O}_{2}$ induced current is consistent with channel opening, whereas the $\sim+30 \mathrm{mV}$ reversal potential in $\mathrm{Na}^{+}$-containing nASW suggests the conductance is nonselective for cations. Depending on specific ionic permeability, cation channels can have a wide range of reversal potentials $(-40$ to $+50 \mathrm{mV}$; Partridge et al., 1994; Clapham, 2003). The bag cell neuron $\mathrm{H}_{2} \mathrm{O}_{2}$-induced current is dependent on select extracellular cations, i.e., the current is lessened in the absence of extracellular $\mathrm{Ca}^{2+}$, diminished even further whether only $\mathrm{Na}^{+}$is removed, and nearly eliminated when both cations are taken away. In addition, the $\mathrm{Ca}^{2+}-, \mathrm{Na}^{+}-$, or $\mathrm{Na}^{+} / \mathrm{Ca}^{2+}$-free external salines all negatively shift the reversal potential to $\sim-10 \mathrm{mV}$, and drastically reduce any outward cur- rent at more positive voltages. Likely, the channel normally passes more $\mathrm{Na}^{+}$and $\mathrm{Ca}^{2+}$ into the neuron than it does $\mathrm{K}^{+}$out.

The U-shaped current/voltage relationship and $\sim+30 \mathrm{mV}$ reversal potential of the $\mathrm{H}_{2} \mathrm{O}_{2}$-induced current are very similar to that of the bag cell neuron cation channel reported by Wilson et al. (1996). That channel is both sensitive to the removal of extracellular $\mathrm{Ca}^{2+}$, which lowers the conductance and left-shifts the reversal potential, and is modestly blocked by intracellular $\mathrm{Mg}^{2+}$ (Geiger et al., 2009). For the $\mathrm{H}_{2} \mathrm{O}_{2}$-gated channel, $\mathrm{Na}^{+}$- and/or $\mathrm{Ca}^{2+}$-free saline may result in an insufficiency of extracellular cations in the pore; if those cations normally repulse intracellular $\mathrm{Mg}^{2+}$, their absence could enhance the $\mathrm{Mg}^{2+}$ block and impede outward current. There are accounts of TRPC4/5 and TRPM2 channels passing limited outward current following replacement of extracellular $\mathrm{Na}^{+}$and $\mathrm{Ca}^{2+}$ with NMDG (Schaefer et al., 2000, 2002; Kühn and Lückhoff, 2004; Blair et al., 2009).

The pharmacology of the $\mathrm{H}_{2} \mathrm{O}_{2}$ induced current also indicates a cation channel. Both the inward current and depolarization brought about by $\mathrm{H}_{2} \mathrm{O}_{2}$ are inhibited by 9-Pt, an ostensible TRPM4specific inhibitor (Grand et al., 2008; Guinamard et al., 2014), which also blocks the voltage-dependent cation channel (Sturgeon and Magoski, 2013), as well as clotrimazole, a general cation channel blocker that has been found to inhibit TRPM2 (Hill et al., 2004). Furthermore, pretreatment with TTX, which Wilson et al. (1996) showed blocks the voltage-dependent cation channel in bag cell neurons, prevents the $\mathrm{H}_{2} \mathrm{O}_{2}$-induced current. TTX also impacts the action potential burst elicited by $\mathrm{H}_{2} \mathrm{O}_{2}$, which is again reminiscent of Wilson et al. (1996), who found that TTX attenuates the depolarization brought about by opening the voltage-dependent cation channel. It is unlikely that TTX is effecting $\mathrm{Na}^{+}$channels, given that both our laboratory and others rarely observe voltage-gated $\mathrm{Na}^{+}$current in cultured bag cell neurons (Nick et al., 1996; Magoski et al., 2000). Based on similar biophysical and pharmacological properties, the $\mathrm{H}_{2} \mathrm{O}_{2}$-induced current and the current characterized by Wilson et al. (1996) appear to be the same or at the very least share one or more channel subunits.

Lee et al. (2011) demonstrated that inhibiting glutathione peroxidase with mercaptosuccinate increases the intracellular $\mathrm{H}_{2} \mathrm{O}_{2}$ concentration of substantia nigra neurons. Our finding that the $\mathrm{H}_{2} \mathrm{O}_{2}$-induced current is enhanced by mercaptosuccinate suggests glutathione peroxidase normally catalyzes the reduction of $\mathrm{H}_{2} \mathrm{O}_{2}$ in bag cell neurons. Fittingly, the $\mathrm{H}_{2} \mathrm{O}_{2}$-induced current is attenuated by $\mathrm{N}$-acetylcysteine, a precursor for glutathione synthesis (Cotgreave et al., 1991). These findings are in agreement with gating by redox, where greater glutathione bioavailability lessens the current by eliminating more $\mathrm{H}_{2} \mathrm{O}_{2}$. Last, the response is decreased with dithiothreitol, which likely opposes the effects of $\mathrm{H}_{2} \mathrm{O}_{2}$ by keeping sulfhydryl groups on key Cys and/or Met residues in the reduced state (Cleland, 1964). It is presently un- 
known whether redox reactions underlying activation are on associated protein(s) or directly on the channel, as is the case for inwardly rectifying $\mathrm{K}^{+}$channels and various TRPC or TRP vanilloid channels (Bannister et al., 1999; Yoshida et al., 2006).

TRPM2 is expressed in neurons and microglia, and can be triggered by $\mathrm{H}_{2} \mathrm{O}_{2}$ (Perraud et al., 2001; Sano et al., 2001; Kraft et al., 2004; Tong et al., 2006). An increase in endogenous $\mathrm{H}_{2} \mathrm{O}_{2}$ with mercaptosuccinate elevates the firing rate of substantia nigra GABAergic neurons by activating a TRPM2-like channel (Lee et al., 2011, 2013), possibly by oxidation of sulfhydryl groups on TRPM2 Cys residues (Ogawa et al., 2016). Our findings suggest a similar effect in bag cell neurons. NEM, an alkylating agent that is reactive toward thiols (Jakobs et al., 1982), evokes a current which appears analogous to the $\mathrm{H}_{2} \mathrm{O}_{2}$-induced current. Furthermore, addition of $\mathrm{H}_{2} \mathrm{O}_{2}$ after NEM does not induce a response and vice versa. If $\mathrm{H}_{2} \mathrm{O}_{2}$ modifies sulfhydryl groups on Cys residues, it would be unable to induce a response post-NEM application. Based on the redox-type activation mechanism we propose, the Aplysia current may involve a TRPM2-like subunit. That stated, the block by 9-Pt also points to a role for TRPM4-like channels, the mammalian versions of which are, like the bag cell neuron $\mathrm{H}_{2} \mathrm{O}_{2}$ induced current, voltage-dependent (Nilius et al., 2003).

Delivery of $\mathrm{H}_{2} \mathrm{O}_{2}$ to the desheathed, isolated bag cell neuron cluster can elicit spiking. Because bath-applying $\mathrm{H}_{2} \mathrm{O}_{2}$ alone causes a burst in a minority of clusters, we speculate $\mathrm{H}_{2} \mathrm{O}_{2}$ may need to work in concert with $\mathrm{ACh}$, a known input transmitter that gates an ionotropic receptor on bag cell neurons (White and Magoski, 2012; White et al., 2014). Pressure-ejecting ACh onto one side of the cluster depolarizes a neuron recorded on the opposite side; this is because of the transfer of cholinergic current through electrotonic coupling between neurons within the cluster (Kupfermann and Kandel, 1970; Dargaei et al., 2014; White et al., 2018). When $\mathrm{H}_{2} \mathrm{O}_{2}$ is bath-applied subsequent to the ACh pressure-ejection, it consistently provokes an afterdischarge-like burst. ACh may facilitate $\mathrm{H}_{2} \mathrm{O}_{2}$-dependent opening of the voltage-dependent cation channel, either through direct depolarization or initiating an as yet unidentified intracellular pathway. Work by our laboratory and others indicates that if one bag cell neuron is bursting within the cluster, all other neurons also spike synchronously (Kupfermann and Kandel, 1970; Brown and Mayeri, 1989; Dargaei et al., 2014). Thus, it is reasonable to assume that the $\mathrm{H}_{2} \mathrm{O}_{2}$-induced afterdischarge-like response represents en masse firing of the cluster.

Activating PKC in bag cell neurons is sufficient to turn on $\mathrm{H}_{2} \mathrm{O}_{2}$ production (Munnamalai et al., 2014). Given that $\mathrm{PKC}$ is triggered during the afterdischarge (Wayne et al., 1999), and $\mathrm{H}_{2} \mathrm{O}_{2}$ exposure depolarizes bag cell neurons, as well as elicits prolonged action potential firing similar to the afterdischarge, it is possible that $\mathrm{H}_{2} \mathrm{O}_{2}$ is a signaling molecule for the afterdischarge. The $\mathrm{H}_{2} \mathrm{O}_{2}$-induced nonselective cation current may maintain the afterdischarge, thereby ensuring egg-laying hor-

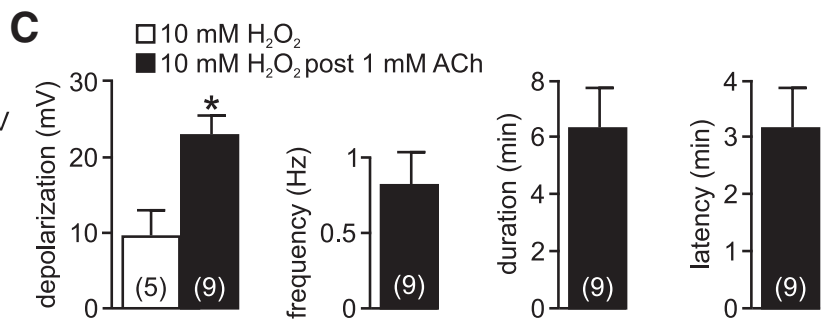

$10 \mathrm{mM} \mathrm{H}_{2} \mathrm{O}_{2}$ 
Brown RO, Mayeri E (1989) Positive feedback by autoexcitory neuropeptides in neuroendocrine bag cells of Aplysia. J Neurosci 9:1443-1451.

Chakfe Y, Bourque CW (2000) Excitatory peptides and osmotic pressure modulate mechanosensitive cation channels in concert. Nat Neurosci 3:572-579.

Chang DJ, Lim CS, Lee SH, Kaang BK (2003) Hydrogen peroxide modulates $\mathrm{K}^{+}$ion currents in cultured Aplysia sensory neurons. Brain Res 970:159-168.

Chen BT, Avshalumov MV, Rice ME (2001) $\mathrm{H}_{2} \mathrm{O}_{2}$ is a novel, endogenous modulator of synaptic dopamine release. J Neurophysiol 85:2468-2476.

Chicheportiche R, Balerna M, Lombet A, Romey G, Lazdunski M (1980) Synthesis of new, highly radioactive tetrodotoxin derivatives and their binding properties to the sodium channel. Eur J Biochem 104:617-625.

Clapham DE (2003) TRP channels as cellular sensors. Nature 426:517-524.

Cleland WW (1964) Dithiothreitol, a new protective reagent for SH groups. Biochemistry 3:480-482.

Colmers WF, Lewis DV Jr, Wilson WA (1982) $\mathrm{Cs}^{+}$loading reveals $\mathrm{Na}^{+}$dependent persistent inward current and negative slope resistance region in Aplysia giant neurons. J Neurophysiol 48:1191-2000.

Conn PJ, Kaczmarek LK (1989) The bag cell neurons of Aplysia: a model for the study of the molecular mechanisms involved in the control of prolonged animal behaviors. Mol Neurobiol 3:237-273.

Cotgreave I, Moldéus P, Schuppe I (1991) The metabolism of $N$-acetylcysteine by human endothelial cells. Biochem Pharmacol 42:13-16.

Dargaei Z, Colmers PL, Hodgson HM, Magoski NS (2014) Electrical coupling between Aplysia bag cell neurons: characterization and role in synchronous firing. J Neurophysiol 112:2680-2696.

DeRiemer SA, Kaczmarek LK, Lai Y, McGuinness TL, Greengard P (1984) Calcium/calmodulin-dependent protein phosphorylation in the nervous system of Aplysia. J Neurosci 4:1618-1625.

Derjean D, Bertrand S, Nagy F, Shefchyk SJ (2005) Plateau potentials and membrane oscillations in parasympathetic preganglionic neurones and intermediolateral neurones in the rat lumbosacral spinal cord. J Physiol 563:583-596.

Di Prisco GV, Pearlstein E, Robitaille R, Dubuc R (1997) Role of sensoryevoked NMDA plateau potentials in the initiation of locomotion. Science 278:1122-1125.

Dong HW, Hayar A, Callaway J, Yang XH, Nai Q, Ennis M (2009) Group I mGluR activation enhances $\mathrm{Ca}^{2+}$-dependent nonselective cation currents and rhythmic bursting in main olfactory bulb external tufted cells. J Neurosci 29:11943-11953.

Dringen R, Kussmaul L, Hamprecht B (1998) Rapid clearance of tertiary butyl hydroperoxide by cultured astroglial cells via oxidation of glutathione. Glia 23:139-145.

Egorov AV, Hamam BN, Fransén E, Hasselmo ME, Alonso AA (2002) Graded persistent activity in entorhinal cortex neurons. Nature 420:173178.

Fink LA, Connor JA, Kaczmarek LK (1988) Inositol trisphosphate releases intracellularly stored calcium and modulates ion channels in molluscan neurons. J Neurosci 8:2544-2555.

Fisher TE, Levy S, Kaczmarek LK (1994) Transient changes in intracellular calcium associated with a prolonged increase in excitability in neurons of Aplysia californica. J Neurophysiol 71:1254-1257.

Fontayne A, Dang PM, Gougerot-Pocidalo MA, El-Benna J (2002) Phosphorylation of p47phox sites by PKC alpha, beta II, delta, and zeta: effect on binding to 22 phox and on NADPH oxidase activation. Biochemistry 41:7743-7750.

Gardam KE, Magoski NS (2009) Regulation of cation channel voltage and $\mathrm{Ca}^{2+}$ dependence by multiple modulators. J Neurophysiol 102:259-271.

Geiger JE, Hickey CM, Magoski NS (2009) $\mathrm{Ca}^{2+}$ entry through a nonselective cation channel in Aplysia bag cell neurons. Neuroscience 162: 1023-1038.

Grand T, Demion M, Norez C, Mettey Y, Launay P, Becq F, Bois P, Guinamard R (2008) 9-phenanthrol inhibits human TRPM4 but not TRPM5 cationic channels. Br J Pharmacol 153:1697-1705.

Gregory JD (1955) The stability of $N$-ethylmaleimide and its reaction with sulfhydryl groups. J Am Chem Soc 77:3922-3923.

Groten CJ, Magoski NS (2015) PKC enhances the capacity for secretion by rapidly recruiting covert voltage-gated $\mathrm{Ca}^{2+}$ channels to the membrane. J Neurosci 35:2747-2765.

Guinamard R, Hof T, Del Negro CA (2014) The TRPM4 channel inhibitor 9-phenanthrol. Br J Pharmacol 171:1600-1613.
Gutteridge JM, Halliwell B (1992) Comments on review of free radical in biology and medicine, second edition. Free Radic Biol Med 12:93-95.

Halliwell B (1992) Reactive oxygen species and the central nervous system. J Neurochem 59:1609-1623.

Hatcher NG, Sweedler JV (2008) Aplysia bag cells function as a distributed neurosecretory network. J Neurophysiol 99:333-343.

Hernandes MS, Britto LR (2012) NADPH oxidase and neurodegeneration. Curr Neuropharmacol 10:321-327.

Herson PS, Ashford ML (1997) Activation of novel non-selective cation channel by alloxan and $\mathrm{H}_{2} \mathrm{O}_{2}$ in the rat insulin-secreting cell line in CRIG1. J Physiol 501:59-66.

Herson PS, Lee K, Pinnock RD, Hughes J, Ashford ML (1999) Hydrogen peroxide induces intracellular calcium overload by activation of a nonselective cation channel in an insulin-secreting cell line. J Biol Chem 274:833-841.

Hickey CM, Geiger JE, Groten CJ, Magoski NS (2010) Mitochondrial Ca ${ }^{2+}$ activates a cation current in Aplysia bag cell neurons. J Neurophysiol 103:1543-1556.

Hickey CM, Groten CJ, Sham L, Carter CJ, Magoski NS (2013) Voltagegated $\mathrm{Ca}^{2+}$ influx and mitochondrial $\mathrm{Ca}^{2+}$ initiate secretion from Aplysia neuroendocrine cells. Neuroscience 250:755-772.

Hill K, McNulty S, Randall AD (2004) Inhibition of TRPM2 channels by the antifungal agents clotrimazole and econazole. Naunyn Schmiedebergs Arch Pharmacol 370:227-237.

Hill K, Tigue NJ, Kelsell RE, Benham CD, McNulty S, Schaefer M, Randall AD (2006) Characterisation of recombinant rat TRPM2 and a TRPM2-like conductance in cultured rat striatal neurones. Neuropharmacology 50: 89-97.

Hofmann T, Obukhov AG, Schaefer M, Harteneck C, Gudermann T, Schultz G (1999) Direct activation of human TRPC6 and TRPC3 channels by diacylglycerol. Nature 397:259-263.

Hoshi T, Heinemann S (2001) Regulation of cell function by methionine oxidation and reduction. J Physiol 531:1-11.

Huang BK, Sikes HD (2014) Quantifying intracellular hydrogen peroxide perturbations in terms of concentration. Redox Biol 2:955-962.

Hung AY, Magoski NS (2007) Activity-dependent initiation of a prolonged depolarization in Aplysia bag cell neurons: role for a cation channel. J Neurophysiol 97:2465-2479.

Jakobs KH, Lasch P, Minuth M, Aktories K, Schultz G (1982) Uncoupling of $\alpha$-adrenoceptor-mediated inhibition of human platelet adenylate cyclase by $N$-ethylmaleimide. J Biol Chem 257:2829-2833.

Jones DP, Eklöw L, Thor H, Orrenius S (1981) Metabolism of hydrogen peroxide in isolated hepatocytes: relative contributions of catalase and glutathione peroxidase in decomposition of endogenously generated $\mathrm{H}_{2} \mathrm{O}_{2}$. Arch Biochem Biophys 210:505-516.

Kaczmarek LK, Jennings KR, Strumwasser F (1982) An early sodium and late calcium phase in the afterdischarge of peptide-secreting neurons of Aplysia. Brain Res 238:105-115.

Kamsler A, Segal M (2004) Hydrogen peroxide as a diffusible signal molecule in synaptic plasticity. Mol Neurobiol 29:167-178.

Kishida KT, Klann E (2007) Sources and targets of reactive oxygen species in synaptic plasticity and memory. Antioxid Redox Signal 9:233-244.

Knauer B, Jochems A, Valero-Aracama MJ, Yoshida M (2013) Long-lasting intrinsic persistent firing in rat CA1 pyramidal cells: a possible mechanism for active maintenance of memory. Hippocampus 23:820-831.

Knox RJ, Jonas EA, Kao LS, Smith PJ, Connor JA, Kaczmarek LK (1996) $\mathrm{Ca}^{2+}$ influx and activation of a cation current are coupled to intracellular $\mathrm{Ca}^{2+}$ release in peptidergic neurons of Aplysia californica. J Physiol 494: $627-639$.

Kourie JI (1998) Interaction of reactive oxygen species with ion transport mechanisms. Am J Physiol 275:C1-C24.

Kraft R, Grimm C, Grosse K, Hoffmann A, Sauerbruch S, Kettenmann H, Schultz G, Harteneck C (2004) Hydrogen peroxide and ADP-ribose induce TRPM2-mediated calcium influx and cation currents in microglia. Am J Physiol Cell Physiol 286:C129-C137.

Kramer RH, Zucker RS (1985) Calcium-dependent inward current in Aplysia bursting pace-maker neurons. J Physiol 362:107-130.

Kühn FJ, Lückhoff A (2004) A sites of the NUDT9-H domain critical for ADP-ribose activation of the cation channel TRPM2. J Biol Chem 279: 46431-46437.

Kupfermann I, Kandel ER (1970) Electrophysiological properties and func- 
tional interconnections of two symmetrical neurosecretory clusters (bag cells) in abdominal ganglion of Aplysia. J Neurophysiol 33:865-876.

Lee CR, Witkovsky P, Rice ME (2011) Regulation of substantia nigra pars reticulata GABAergic neuron activity by $\mathrm{H}_{2} \mathrm{O}_{2}$ via flufenamic acidsensitive channels and $\mathrm{K}^{+}$-ATP channels. Front Syst Neurosci 5:14.

Lee CR, Machold RP, Witkovsky P, Rice ME (2013) TRPM2 channels are required for NMDA-induced burst firing and contribute to $\mathrm{H}_{2} \mathrm{O}_{2}$ dependent modulation in substantia nigra pars reticulate GABAergic neurons. J Neurosci 33:1157-1568.

Lee DK, Jeong JH, Chun SK, Chua S Jr, Jo YH (2015a) Interplay between glucose and leptin signalling determines the strength of GABAergic synapses at POMC neurons. Nat Commun 6:6618.

Lee CR, Patel JC, O’Neill B, Rice ME (2015b) Inhibitory and excitatory neuromodulation by hydrogen peroxide: translating energetics to information. J Physiol 593:3431-3446.

Loechner KJ, Azhderian EM, Dreyer R, Kaczmarek LK (1990) Progressive potentiation of peptide release during a neuronal discharge. J Neurophysiol 63:738-744.

Loechner KJ, Knox RJ, Connor JA, Kaczmarek LK (1992) Hyperosmotic media inhibit voltage-dependent calcium influx and peptide release in Aplysia neurons. J Membr Biol 128:41-52.

Lupinsky DA, Magoski NS (2006) $\mathrm{Ca}^{2+}$-dependent regulation of a nonselective cation channel from Aplysia bag cell neurones. J Physiol 575: 491-506.

Magoski NS, Kaczmarek LK (2005) Association/dissociation of a channelkinase complex underlies state-dependent modulation. J Neurosci 25: 8037-8047.

Magoski NS, Knox RJ, Kaczmarek LK (2000) Activation of a $\mathrm{Ca}^{2+}$ permeable cation channel produces a prolonged attenuation of intracellular $\mathrm{Ca}^{2+}$ release in Aplysia bag cell neurones. J Physiol 522:271-283.

Major G, Tank D (2004) Persistent neuronal activity: prevalence and mechanisms. Curr Opin Neurobiol 14:675-684.

Matsumoto M, Sasaki K, Sato M, Shozushima M, Takashima K (1988) Dopamine-induced depolarizing responses associated with negative slope conductance in LB-cluster neurones of Aplysia. J Physiol 407:199-213.

Michel S, Wayne NL (2002) Neurohormone secretion persists after postafterdischarge membrane depolarization and cytosolic calcium elevation in peptidergic neurons in intact nervous tissue. J Neurosci 22:9063-9069.

Miller EW, Bian SX, Chang CJ (2007) A fluorescent sensor for imaging reversible redox cycles in living cells. J Am Chem Soc 129:3458-3459.

Morisset V, Nagy F (2000) Plateau potential-dependent windup of the response to primary afferent stimuli in rat dorsal horn neurons. Eur J Neurosci 12:3087-3095.

Mrejeru A, Wei A, Ramirez JM (2011) Calcium-activated non-selective cation currents are involved in generation of tonic and bursting activity in dopamine neurons of the substantia nigra pars compacta. J Physiol 589: 2497-2514.

Munnamalai V, Weaver CJ, Weisheit CE, Venkatraman P, Agim ZS, Quinn MT, Suter DM (2014) Bidirectional interactions between NOX2-type NADPH oxidase and the F-actin cytoskeleton in neuronal growth cones. J Neurochem 130:526-540.

Narahashi T, Moore JW, Scott WR (1964) Tetrodotoxin blockage of sodium conductance increase in lobster giant axons. J Gen Physiol 47:965-974.

Nick TA, Kaczmarek LK, Carew TJ (1996) Ionic currents underlying developmental regulation of repetitive firing in Aplysia bag cell neurons. J Neurosci 16:7583-7598.

Nilius B, Prenen J, Droogmans G, Voets T, Vennekens R, Freichel M, Wissenbach U, Flockerzi V (2003) Voltage dependence of the $\mathrm{Ca}^{2+}$ activated cation channel TRPM4. J Biol Chem 278:30813-30820.

Ogawa N, Kurokawa T, Mori Y (2016) Sensing of redox status by TRP channels. Cell Calcium 60:115-122.

Ohashi M, Hirano T, Watanabe K, Katsumi K, Ohashi N, Baba H, Endo N, Kohno T (2016) Hydrogen peroxide modulates synaptic transmission in ventral horn neurons of the rat spinal cord. J Physiol 594:115-134.

Okada T, Inoue R, Yamazaki K, Maeda A, Kurosaki T, Yamakuni T, Tanaka I, Shimizu S, Ikenaka K, Imoto K, Mori Y (1999) Molecular and functional characterization of a novel mouse transient receptor potential protein homologue TRP7. $\mathrm{Ca}^{2+}$-permeable cation channel that is constitutively activated and enhanced by stimulation of $\mathrm{G}$ protein-coupled receptor. J Biol Chem 274:27359-27370.

Olah ME, Jackson MF, Li H, Perez Y, Sun HS, Kiyonaka S, Mori Y, Tymianski
M, MacDonald JF (2009) $\mathrm{Ca}^{2+}$-dependent induction of TRPM2 currents in hippocampal neurons. J Physiol 587:965-979.

Partridge LD, Swandulla D (1987) Single ca-activated cation channels in bursting neurons of Helix. Pflugers Arch 410:627-631.

Partridge LD, Thompson SH, Smith SJ, Connor JA (1979) Current-voltage relationships of repetitively firing neurons. Brain Res 164:69-79.

Partridge LD, Müller TH, Swandulla D (1994) Calcium-activated nonselective channels in the nervous system. Brain Res Brain Res Rev 19:319-325.

Perraud AL, Fleig A, Dunn CA, Bagley LA, Launay P, Schmitz C, Stokes AJ, Zhu Q, Bessman MJ, Penner R, Kinet JP, Scharenberg AM (2001) ADPribose gating of the calcium-permeable LTRPC2 channel revealed by nudix motif homology. Nature 411:595-599.

Pinsker HM, Dudek FE (1977) Bag cell control of egg laying in freely behaving Aplysia. Science 197:490-493.

Ratté S, Karnup S, Prescott SA (2018) Nonlinear relationship between spike-dependent calcium influx and TRPC channel activation enables robust persistent spiking in neurons of the anterior cingulate cortex. J Neurosci 38:1788-1801.

Rekling JC, Feldman JL (1997) Calcium-dependent plateau potentials in rostral ambiguous neurons in the newborn mouse brain stem in vitro. J Neurophysiol 78:2483-2492.

Rothman BS, Weir G, Dudek FE (1983) Egg-laying hormone: direct action on the ovotestis of Aplysia. Gen Comp Endocrinol 52:134-141.

Roubos EW, van de Ven AM, ter Maat A (1990) Quantitative ultrastructural tannic acid study of the relationship between electrical activity and peptide secretion by the bag cell neurons of Aplysia californica. Neurosci Lett 111:1-6.

Sano Y, Inamura K, Miyake A, Mochizuki S, Yokoi H, Matsushime H, Furuichi K (2001) Immunocyte $\mathrm{Ca}^{2+}$ influx system mediated by LTRPC2. Science 293:1327-1330.

Schaefer M, Plant TD, Obukhov AG, Hofmann T, Gudermann T, Schultz G (2000) Receptor-mediated regulation of the nonselective cation channels TRPC4 and TRPC5. J Biol Chem 275:17517-17526.

Schaefer M, Plant TD, Stresow N, Albrecht N, Schultz G (2002) Functional differences between TRPC4 splice variants. J Biol Chem 277:3752-3759.

Shpak G, Zylbertal A, Yarom Y, Wagner S (2012) Calcium-activated sustained firing responses distinguish accessory from main olfactory bulb mitral cells. J Neurosci 32:6251-6262.

Sidiropoulou K, Lu FM, Fowler MA, Xiao R, Phillips C, Ozkan ED, Zhu MX, White FJ, Cooper DC (2009) Dopamine modulates an mGluR5mediated depolarization underlying prefrontal persistent activity. Nat Neurosci 12:190-199.

Smith MA, Herson PS, Lee K, Pinnock RD, Ashford ML (2003) Hydrogenperoxide-induced toxicity of rat striatal neurones involves activation of a non-selective cation channel. J Physiol 547:417-425.

Sohal RS, Orr WC (2012) The redox stress hypothesis of aging. Free Radic Biol Med 52:539-555.

Stuart DK, Strumwasser F (1980) Neuronal sites of action of a neurosecretory peptide, egg-laying hormone, in Aplysia californica. J Neurophysiol 43:499-519.

Sturgeon RM, Magoski NS (2013) Pharmacological characterization and modulation of a cation channel in Aplysia bag cell neurons. Soc Neurosci Abstr 39:515.16.

Sturgeon RM, Magoski NS (2016) Diacylglycerol-mediated regulation of Aplysia bag cell neuron excitability requires protein kinase C. J Physiol 594:5573-5592.

Sturgeon RM, Magoski NS (2018) A closely associated phospholipase C regulates cation channel function through phosphoinositide hydrolysis. J Neurosci 38:7622-7634.

Sturgeon RM, Chauhan AK, Magoski NS (2018) Neuroendocrine control of reproduction in Aplysia by the bag cell neurons. In: Model animals in neuroendocrinology: from worm to mouse to man (Ludwig M, Levkowitz G, eds), pp 29-58. Hoboken, NJ: Wiley.

Swandulla D, Lux HD (1985) Activation of a nonspecific cation conductance by intracellular $\mathrm{Ca}^{2+}$ elevation in bursting pacemaker neurons of Helix pomatia. J Neurophysiol 54:1430-1443.

Tahvildari B, Alonso AA, Bourque CW (2008) Ionic basis of ON and OFF persistent activity in layer III lateral entorhinal cortical principal neurons. J Neurophysiol 99:2006-2011.

Tam AK, Gardam KE, Lamb S, Kachoei BA, Magoski NS (2011) Role for 
protein kinase C in controlling Aplysia bag cell neuron excitability. Neuroscience 179:41-55.

Tong Q, Zhang W, Conrad K, Mostoller K, Cheung JY, Peterson BZ, Miller BA (2006) Regulation of the transient receptor potential channel TRPM2 by the $\mathrm{Ca}^{2+}$ sensor calmodulin. J Biol Chem 281:9076-9085.

Wayne NL, Lee W, Kim YJ (1999) Persistent activation of calcium-activated and calcium independent protein kinase $\mathrm{C}$ in response to electrical afterdischarge from peptidergic neurons of Aplysia. Brain Res 834:211-213.

White SH, Magoski NS (2012) Acetylcholine-evoked afterdischarge in Aplysia bag cell neurons. J Neurophysiol 107:2672-2685.

White SH, Carter CJ, Magoski NS (2014) A potentially novel nicotinic receptor in Aplysia neuroendocrine cells. J Neurophysiol 112:446-462.

White SH, Sturgeon RM, Gu Y, Nensi A, Magoski NS (2018) Tyrosine phosphorylation determines afterdischarge initiation by regulating an ionotropic cholinergic receptor. Neuroscience 372:273-288.

Wilson GF, Richardson FC, Fisher TE, Olivera BM, Kaczmarek LK (1996) Identification and characterization of a $\mathrm{Ca}^{2+}$-sensitive nonspecific cation channel underlying prolonged repetitive firing in Aplysia neurons. J Neurosci 16:3661-3671

Wilson GF, Magoski NS, Kaczmarek LK (1998) Modulation of a calcium-sensitive nonspecific cation channel by closely associated protein kinase and phosphatase activities. Proc Natl Acad Sci U S A 95:10938-10943.

Yan HD, Villalobos C, Andrade R (2009) TRPC channels mediate a muscarinic receptor-induced afterdepolarization in cerebral cortex. J Neurosci 29:10038-10046.

Yoshida T, Inoue R, Morii T, Takahashi N, Yamamoto S, Hara Y, Tominaga M, Shimizu S, Sato Y, Mori Y (2006) Nitric oxide activates TRP channels by cysteine S-nitrosylation. Nat Chem Biol 2:596-607.

Zhang Y, Kaczmarek LK (2008) Bag cell neurons. Scholarpedia 3:4095.

Zhu X, Jiang M, Birnbaumer L (1998) Receptor-activated $\mathrm{Ca}^{2+}$ influx via human Trp3 stably expressed in human embryonic kidney (HEK) 293 cells: evidence for a non-capacitative $\mathrm{Ca}^{2+}$ entry. J Biol Chem 273:133142. 